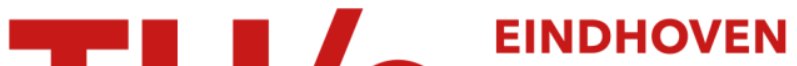 UNIVERSITY OF TECHNOLOGY
}

\section{Expanding thermal plasma deposition of Al-doped ZnO: On the effect of the plasma chemistry on film growth mechanisms}

Citation for published version (APA):

Williams, B. L., Ponomarev, M., Verheijen, M. A., Knoops, H. C. M., Duval, L. A. A., van de Sanden, M. C. M., \& Creatore, M. (2016). Expanding thermal plasma deposition of Al-doped ZnO: On the effect of the plasma chemistry on film growth mechanisms. Plasma Processes and Polymers, 13(1), 54-69.

https://doi.org/10.1002/ppap.201500179

DOI:

10.1002/ppap.201500179

Document status and date:

Published: 01/01/2016

Document Version:

Publisher's PDF, also known as Version of Record (includes final page, issue and volume numbers)

Please check the document version of this publication:

- A submitted manuscript is the version of the article upon submission and before peer-review. There can be important differences between the submitted version and the official published version of record. People interested in the research are advised to contact the author for the final version of the publication, or visit the $\mathrm{DOI}$ to the publisher's website.

- The final author version and the galley proof are versions of the publication after peer review.

- The final published version features the final layout of the paper including the volume, issue and page numbers.

Link to publication

\section{General rights}

Copyright and moral rights for the publications made accessible in the public portal are retained by the authors and/or other copyright owners and it is a condition of accessing publications that users recognise and abide by the legal requirements associated with these rights.

- Users may download and print one copy of any publication from the public portal for the purpose of private study or research.

- You may not further distribute the material or use it for any profit-making activity or commercial gain

- You may freely distribute the URL identifying the publication in the public portal.

If the publication is distributed under the terms of Article $25 \mathrm{fa}$ of the Dutch Copyright Act, indicated by the "Taverne" license above, please follow below link for the End User Agreement:

www.tue.nl/taverne

Take down policy

If you believe that this document breaches copyright please contact us at:

openaccess@tue.nl

providing details and we will investigate your claim. 


\title{
Expanding Thermal Plasma Deposition of Al-Doped ZnO: On the Effect of the Plasma Chemistry on Film Growth Mechanisms
}

\author{
Benjamin L. Williams, Mikhail V. Ponomarev, Marcel A. Verheijen, \\ Harm C. M. Knoops, Abhinaya Chandramohan, Leo Duval, \\ Mauritius C. M. van de Sanden, Mariadriana Creatore*
}

This work presents a review of expanding thermal plasma - chemical vapour deposition (ETPCVD) of Al-doped ZnOtransparent conducting oxides (TCOs), alongside new results providing insights into the role of the plasma chemistry on film microstructure. Standard growth conditions generate high resistivities $\left(>10^{-3} \Omega \cdot \mathrm{cm}\right)$ at low film thicknesses $(<300 \mathrm{~nm})$ as a result of a high grain boundary and void density. Microscopy studies of the early growth stage reveal that a high nucleation probability and strong $<0002>$-texture are the causes of this microstructure. We investigate how the precursor feed composition (diethylzinc-to- $\mathrm{O}_{2}$ flow rate ratio) can be utilised to modify the growth mechanism and consequently reduce film resistivity $\left(\sim 10^{-4} \Omega \cdot \mathrm{cm}\right)$, focussing on the role that this flow rate ratio has on the plasma chemistry developing in the downstream region of the expanding plasma (as supported by Langmuir probe and mass spectrometry measurements).

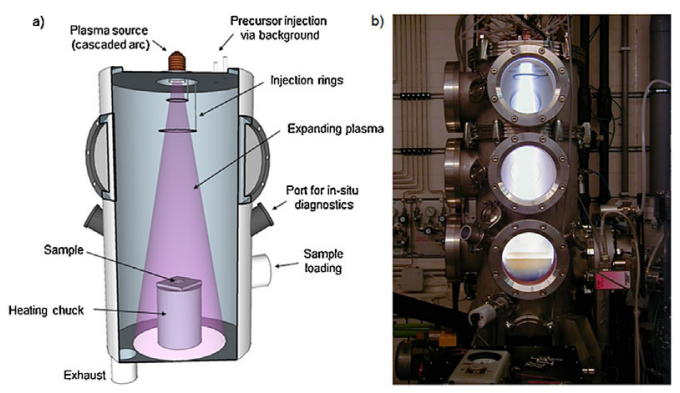

\section{Introduction}

With the widespread presence and expansion of the electronics industry comes the increasing need for highquality transparent and conductive thin-films for use, primarily, as transparent electrodes in various optoelectronic devices, such as solar cells. Indium tin oxide (ITO) has long been the state-of-the-art transparent

M. Creatore, B. L. Williams, M. V. Ponomarev, M. A. Verheijen, H. C. M. Knoops, A. Chandramohan, L. Duval, M. C. M. van de Sanden Department of Applied Physics, Eindhoven University of

Technology, 5600 MBEindhoven, The Netherlands

E-mail: m.creatore@tue.nl

M. C. M. van de Sanden

Dutch Institute for Fundamental Energy (DIFFER), P.O.Box 6336,

$5600 \mathrm{HH}$, Eindhoven, The Netherlands

M. Creatore

Solliance, High Tech Campus 21, 5656 AE, Eindhoven, The

Netherlands conducting oxide (TCO), but owing to the projected scarcity of indium and the associated increase in its price, there has been a resurgence in research and industrial production of zinc oxide as an alternative in the last 15 years. Intrinsic $\mathrm{ZnO}$ has a direct optical band-gap at $\sim 3.37 \mathrm{eV}(\sim 370 \mathrm{~nm}),{ }^{[1]}$ and when doped (most commonly with group III elements such as $\mathrm{Al}, \mathrm{B}$, or $\mathrm{Ga}$ ) can exhibit resistivities as low as $8 \cdot 10^{-5} \Omega \cdot \mathrm{cm} \cdot{ }^{[2]} \mathrm{ZnO}$ is relatively abundant, may be easily fabricated by various dry and wet methods, is structurally stable under hydrogen plasma exposure, ${ }^{[3]}$ and can be chemically stable up to $700^{\circ} \mathrm{C}^{[4]}$ Films of Al-doped $\mathrm{ZnO}$ (ZnO:Al) have been generated by sputtering, pulsed laser deposition (PLD), sol-gel methods, atomic layer deposition (ALD) and various types of chemical vapour deposition (CVD). ${ }^{[2,4-27]}$ In this article, growth of $\mathrm{ZnO}: \mathrm{Al}$ by the expanding thermal-plasma CVD (ETP-CVD) technique ${ }^{[28-31]}$ will be reviewed. ETP-CVD has already been shown to provide process scalability at high growth rates ${ }^{[32-34]}$ (up to $5 \mathrm{~nm} / \mathrm{s})$ and low processing temperatures $\left(<200^{\circ} \mathrm{C}\right)$ with negligible ion bombardment. ${ }^{[35,36]}$ At the same time, the 
decoupling of plasma generation, precursor chemistry and film growth processes (i.e. its remote character) makes ETP-CVD an ideal system to analyse and understand a deposition process, as we have shown in, e.g. ${ }^{[37-41]}$

In the past years, we have adopted the ETP process for the deposition of poly-crystalline transparent conductive ZnO:Al layers from diethylzinc(DEZ, $\left.\mathrm{Zn}\left(\mathrm{C}_{2} \mathrm{H}_{5}\right)_{2}\right) /$ trimethylaluminum(TMA, $\left.\mathrm{Al}\left(\mathrm{CH}_{3}\right)_{3}\right) / \mathrm{O}_{2}$-fed mixtures. ${ }^{[42-46]}$ Our previous efforts have been dedicated to the correlation between the morphology of the $\mathrm{ZnO}: \mathrm{Al}$ layers (in terms of grain size and crystal orientation) and their optoelectronic properties (in terms of resististivity, $\rho$, carrier concentration, $n$, and mobility, $\mu$ ). This progress is reviewed here alongside additional morphological studies examining the early stages of growth. Additionally, this present study addresses our very recent efforts in gaining insight into the influence of the plasma chemistry on the morphology development of the $\mathrm{ZnO}$ :Al layers. Therefore this contribution is intended to provide a comprehensive overview of the entire deposition process. The paper is organised as follows: Section 2 presents an overview of the CVD-based processes reported in literature for the deposition of (doped) ZnO. Section 3 presents the experimental details and the plasma and thin film diagnostic tools. Section 4 addresses the microstructural development of poly-crystalline $\mathrm{ZnO}: \mathrm{Al}$ as a function of the film thickness and reviews the correlation between the microstructure and the opto-electrical properties. Parallels to other deposition methodologies for the generation of $\mathrm{ZnO}$ films are made where possible. Section 5 presents the plasma chemistry channels developing from the injection of the DEZ deposition precursor in an $\mathrm{O}_{2}$-fed expanding thermal plasma, and how these channels are affected by the DEZ flow rate. These results are then further linked to the surface processes during the $\mathrm{ZnO}: \mathrm{Al}$ growth, and in turn, to the $\mathrm{ZnO}: \mathrm{Al}$ properties.

\section{CVD Processes for (Doped) ZnO Layers}

Table 1 collates the $\mathrm{ZnO}$ material properties achieved from the use of various deposition techniques - note that this compilation predominantly focuses on the results from various chemical vapour deposition (CVD) methods, ALD, PLD, and radio-frequency magnetron sputtering (RFMS) results are taken as representative of the respective techniques. The lowest resistivity reported here is $8 \cdot 10^{-5} \Omega \cdot \mathrm{cm}$ for a $300 \mathrm{~nm} \mathrm{ZnO}$ :Ga film (sheet resistance, $R_{\text {sheet }}=1.6 \Omega / \square$ ), which was generated by PLD from a $\mathrm{ZnO}$ target containing $5 \mathrm{wt} . \% \mathrm{Ga}_{2} \mathrm{O}_{3}$, at a substrate temperature of $300^{\circ} \mathrm{C} .^{[2]} \mathrm{RF}$ magnetron sputtering (RFMS) can also frequently be used for high quality $\mathrm{ZnO}$; Igasaki et al. demonstrated a resistivity of $1.4 \cdot 10^{-4} \Omega \cdot \mathrm{cm}$ for a $300 \mathrm{~nm}$ film grown using a substrate temperature of just $150^{\circ} \mathrm{C} \cdot{ }^{[5]}$ Elsewhere, resistivities as low as $2 \cdot 10^{-4} \Omega \cdot \mathrm{cm}$ have been achieved with RFMS using solely $\mathrm{H}$-doping (ZnO:H), whereby $\mathrm{H}$ was introduced by addition of $\mathrm{H}_{2}$ to the plasma. ${ }^{[4]}$ ALD can generate highly conformal ZnO coatings, with competitive electrical and optical properties for relatively thin films $(<100 \mathrm{~nm})$. Both Al- and B-doping have been successfully employed for $\operatorname{ALD}^{[13,14]}$; the Aldoped process yielded resistivities as low as $7 \cdot 10^{-4} \Omega \cdot \mathrm{cm}$ for films as thin as $75 \mathrm{~nm}$, and can produce suitable contacts for heterojunction c-Si/a-Si solar cells. ${ }^{[12]}$

Various CVD configurations have successfully produced doped-ZnO films with resistivities in the $10^{-4} \Omega \cdot \mathrm{cm}$ regime. Effective employment of $\mathrm{Al}, \mathrm{Ga}, \mathrm{F}$, and $\mathrm{B}$ as the extrinsic dopant has been demonstrated, and the most frequent precursor used for introduction of $\mathrm{Al}$ is trimethylaluminium. The CVD processes listed in Table 1 generally demonstrate higher deposition rates than ALD and RFMS, being as high as $2 \mathrm{~nm} / \mathrm{s}$ for the low pressure metal organic CVD (LP-MOCVD) ZnO:B process reported by Fay et al. ${ }^{[48]}$ The lowest CVD-generated resistivity that is reported is $2.6 \cdot 10^{-4} \Omega \cdot \mathrm{cm}$ for a Ga-doped $800 \mathrm{~nm}$ thick $\mathrm{ZnO}$ layer generated by LP-CVD. ${ }^{[21]}$ Often the deposition temperatures used for MOCVD reach $400^{\circ} \mathrm{C}$, whereas plasmaenhanced CVD (PECVD) can enable ZnO deposition rates of up to $1 \mathrm{~nm} / \mathrm{s}$ at substrates temperature of $200^{\circ} \mathrm{C}$ down to room temperature, as demonstrated by Martín et al. ${ }^{[23]}$ Martín also showed the wide range of resistivity values obtainable (from $10^{-3}$ to $10^{7} \Omega \cdot \mathrm{cm}$ ) by varying the relative flow rates of $\mathrm{Zn}$ and $\mathrm{Al}$ precursors (DEZ and TMA) and $\mathrm{O}_{2}$ and $\mathrm{H}_{2}$ co-reactants, the lowest resistivities being obtained for the highest $\mathrm{H}_{2}$ flow rates.

Many CVD-grown ZnO films exhibit the strong resistivity gradient that typifies the behaviour of ETP-CVD grown ZnO. For example, for LP-MOCVD, Fay et al. reported resistivity decreasing across three orders of magnitude from $2.2 \Omega \cdot \mathrm{cm}$ for a $37 \mathrm{~nm}$ thick film, to $\sim 10^{-3} \Omega \cdot \mathrm{cm}$ for $1000 \mathrm{~nm} .{ }^{[49]}$ For ETP-CVD, Volintiru demonstrated a drop in resistivity from $10^{-1}$ to $10^{-4} \Omega \cdot \mathrm{cm}$ in the thickness range 100-1000 nm. ${ }^{[45]}$ As a result, many of the CVD-entries in Table 1 report the best resistivities for notably thick films (in some cases, exceeding $1000 \mathrm{~nm}$ ). Given that it is often preferred to minimise resistivity at as a low a film thickness as possible (to minimise absorption, to reduce deposition time and precursor usage, and in some cases for design reasons), it is desirable to control this resistivity gradient. Comparatively, the gradient for RF sputter-grown and PLD-grown $\mathrm{ZnO}$ is frequently less pronounced, ranging only within one or two orders of magnitude in many cases $^{[50-55]}$ - remarkably, for PLD, Dong et al. ${ }^{[56]}$ demonstrated resistivities of $9 \cdot 10^{-4} \Omega \cdot \mathrm{cm}$ for a film thickness of just $15 \mathrm{~nm}$, albeit at a relatively low growth rate $(0.1 \mathrm{~nm} / \mathrm{s})$ and using high purity $(4 \mathrm{~N})$ targets. Note that strong resistivity gradients have also occasionally been reported for sputtering. ${ }^{[57]}$ The differing behaviours obtained from 


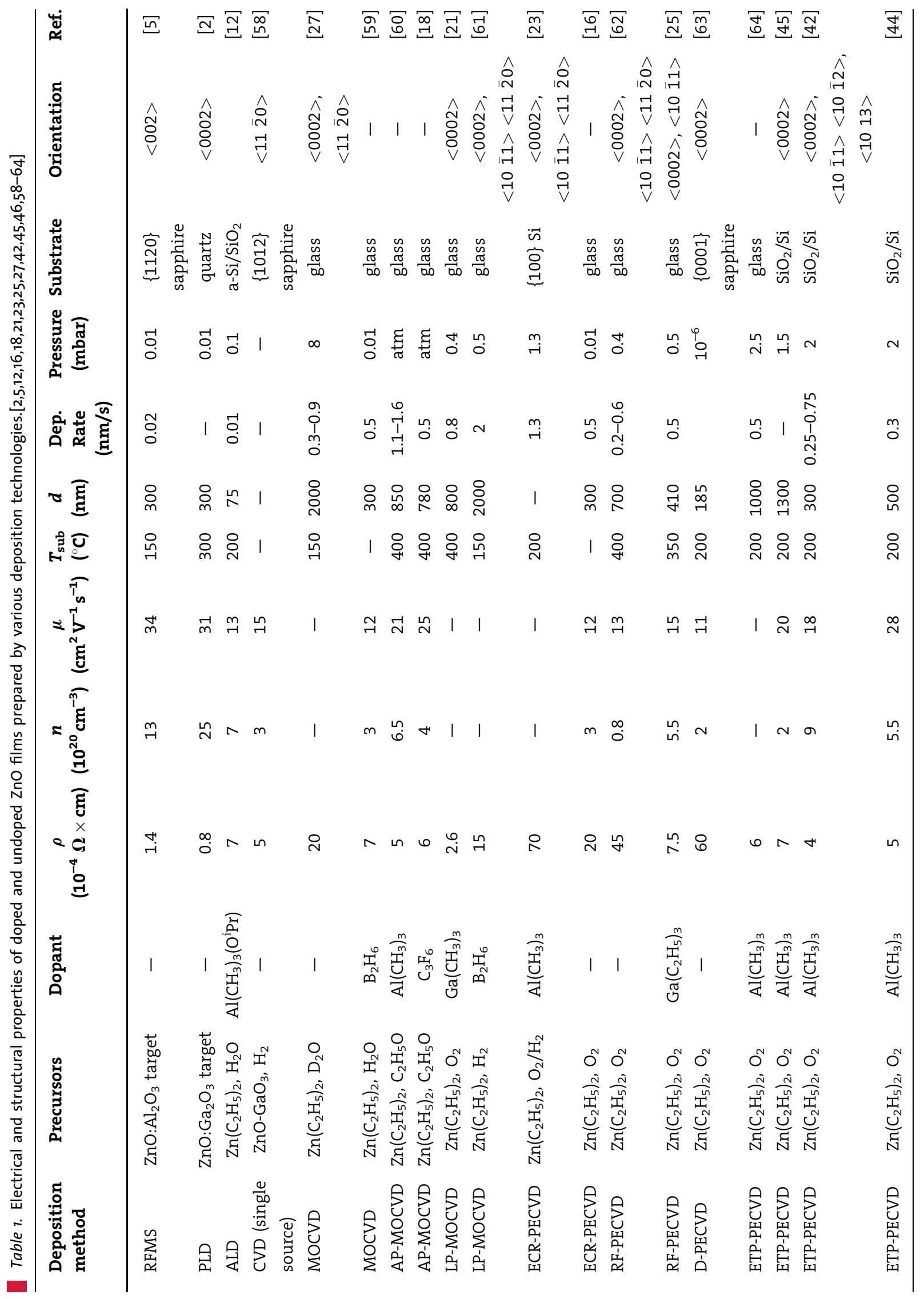


different technologies and process conditions are highly related to the differing growth modes, as is addressed in Sections 4-5.

\section{Experimental Details}

\subsection{Expanding Thermal Plasma Operation}

The expanding thermal plasma (ETP), earlier reported for the deposition of several materials ${ }^{[34,39,41,65]}$ consists of a DC Ar-fed plasma generated at sub-atmospheric pressure (200-600 mbar) in a cascaded arc; see Refs. ${ }^{[35,66]}$ for more details. After generation, the plasma expands supersonically through a nozzle into a low pressure chamber ( $<5 \mathrm{mbar}$ ), where deposition occurs by means of precursor dissociation and a convective flux towards the substrate placed at $50-65 \mathrm{~cm}$ from the nozzle exit. Figures $1(a-b)$ show, respectively, a schematic and a photo of an ETP-CVD reactor. The ionisation degree of the $\mathrm{Ar}$ was measured here to be $3 \%$ (Section 3.3). $\mathrm{H}_{2}, \mathrm{~N}_{2}$, and $\mathrm{Ar} / \mathrm{H}_{2} / \mathrm{N}_{2}$ mixtures can also be used as the ignition gas, but for all $\mathrm{ZnO}$ deposition processes described here, $\mathrm{Ar}$ is used with flows between 1000 and $3000 \mathrm{sccm}$. DC currents from 25 to $90 \mathrm{~A}$ are used, corresponding to an operating voltage of $70-250 \mathrm{~V}$. The generated plasma is thermal with an electron density of $\sim 10^{22} \mathrm{~m}^{-3}$, and electron (and heavy particle) temperature of $1 \mathrm{eV}$. Following supersonic expansion and then shock, the electron and heavy particle temperatures are reduced to $\sim 0.1-0.3 \mathrm{eV}$ and the electron density to $\sim 10^{17}-10^{19} \mathrm{~m}^{-3}$, depending on the deposition precursor flow injected in the downstream region. ${ }^{[35]}$

In the works on $\mathrm{ZnO}: \mathrm{Al}$ deposition summarised in Sections 4 and $5, \mathrm{O}_{2}$ is the chosen oxidant and always injected via a perforated ring placed $6.5 \mathrm{~cm}$ downstream from the plasma source, whereas the $\mathrm{Zn}$ and $\mathrm{Al}$ precursors (DEZ and TMA respectively) are injected either in separate rings in the deposition chamber $(30 \mathrm{~cm}$ downstream from the plasma source, as for results shown in Section 5) or via nozzles $(5 \mathrm{~cm}$ laterally from the plasma source, as for results shown in Section 4) in the background of the chamber. The films grown using nozzle injection or ring
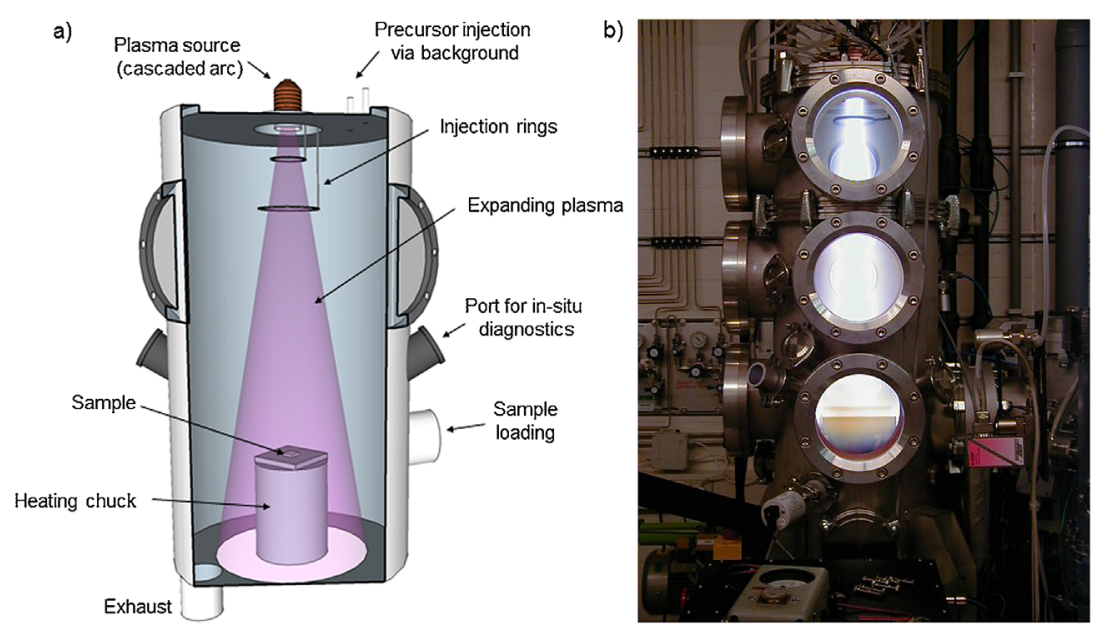

Figure 1. (a) Schematic diagram and (b) photo of expanding thermal plasma chemical vapour deposition (ETP-CVD) reactors. injection of the precursors were highly comparable, and the relative changes in microstructure induced by varying growth conditions (reported in Section 5) were replicated for either injection method. The DEZ and TMA liquid precursors are supplied from liquid vaporizers to the reactor chamber utilizing Bronkhorst Hi-Tec mass flow controllers for vapour flow. Substrates $\left(\mathrm{SiO}_{2} / \mathrm{Si}\right.$ wafers, glass, or $\mathrm{Si}_{3} \mathrm{~N}_{4} \mathrm{TEM}$ window substrates) are held downstream on a temperature controlled $\left(20-400^{\circ} \mathrm{C}\right)$ heating chuck.

It is important to understand that the ETP is the ultimate example of remote plasma configurations: plasma production, active species transport and deposition are geometrically separated. This means that the plasma reactivity, in terms of $\mathrm{Ar}$ ion and electron flow, is: (1) fully controlled and tuned by the arc plasma parameters (arc current and Ar gas flow); (2) easily measured/quantified by means of a Langmuir probe in the downstream region; and (3) responsible for the dissociation paths of the precursors injected in the downstream region.

\subsection{Thin Film and Bulk Diagnostics}

The electrical resistivities of deposited films were measured using a Jandel universal four-point probe (4PP). Carrier concentrations and electrical mobilities were determined via both: (a) Hall measurements by means of a Phystech RH 2010; and (b) extraction from optical models which are fit to spectroscopic ellipsometry (SE) data - the ellipsometry measurements themselves were taken using a J.A. Woollam, Inc. M2000U ellipsometer and the model that was used is described in detail in previous work. ${ }^{[67]}$ Essentially, the model computes the dielectric functions of the films using a linear addition of various oscillators which account for both interband absorption and free carrier interactions. The carrier concentration values determined from ellipsometry match those from Hall measurements and therefore the mobility can also be computed from the 4PP determined resistivity and optically determined carrier concentration (e.g. in the absence of Hall measurements). However, the mobility values directly extracted from the optical model may differ to those of Hall measurements, since the ellipsometry measurements are only sensitive to in-grain properties.

Transmission electron microscopy (TEM) imaging was used to investigate structural and crystallographic properties of $\mathrm{ZnO}: \mathrm{Al}$ films. For cross-sectional imaging, lift-out sample preparation was carried out in a FEI Nova 600 i NanoLab dual-beam system. The cross-sections were then imaged in a Jeol ARM200F TEM in high-angle annular darkfield (HAADF) scanning TEM (STEM) mode. Top-view HAADF STEM images were also taken of ultra-thin $\mathrm{ZnO}$ :Al films grown on transparent $\mathrm{Si}_{3} \mathrm{~N}_{4}$ TEM window substrates. Electron diffraction patterns were acquired at a camera length of $100 \mathrm{~mm}$.

X-ray diffraction measurements were carried out in a PanAlytical X'pert PRO MRD system, using the CuK $\alpha 1$ line as the X-ray 
source. Rutherford Backscattering Spectrometry (RBS) was used to determine the composition of $\mathrm{ZnO}: \mathrm{Al}$ films and to determine the zinc-to-oxygen ratio. RBS measurements were performed using $2 \mathrm{MeV} \mathrm{He}{ }^{+}$ions produced by a high voltage engineering (HVE) 3.5 MV singletron. Ultra-violet-visible (UV-VIS) transmittance measurements were taken using a Shimadzu UV-3600 spectrophotometer equipped with an integrating sphere.

\subsection{Plasma Diagnostics}

In Section 5, the effect of plasma chemistry on the ZnO growth mechanism is reported. For this study, mass-spectrometry (MS) analysis was performed using a Pfeiffer Vacuum Prisma QME 200 quadrupole mass-spectrometer located on the side of the deposition chamber at the substrate level. The chamber species were sampled through a $10 \mu \mathrm{m}$ pinhole, so only stable reaction products could be detected. Since only the DEZ flow rate was changed, the signal intensities of the measured masses were normalized to the one of Ar to exclude any pressure effect. In order to determine the depletion of $\mathrm{O}_{2}$ in the presence of an increasing DEZ flow rate, oxygen-containing ion masses $(\mathrm{m} / \mathrm{z}=16$ and $32 \mathrm{amu})$ have been investigated and the depletion of $\mathrm{O}_{2}$ has been calculated as $D=\left(I_{\text {off }}-I_{\text {on }}\right) / I_{\text {off. }}$. Here, $I_{\text {off }}$ is the signal intensity of the corresponding $\mathrm{m} / \mathrm{z}$ when the plasma source is switched off, and $I_{o n}$ is the signal intensity of the corresponding $m / z$ when the $\mathrm{Ar}$ plasma is switched on and the oxygen, DEZ, and TMA precursors are injected.

As plasma ionisation and dissociation processes are driven in ETP by argon ions $\left(\mathrm{Ar}^{+}\right)$and electrons, ${ }^{[35,68,69]}$ it is essential to determine the $\mathrm{Ar}^{+}$flux produced by the plasma source, i.e. the plasma source ionisation efficiency. Following the procedure described by van Hest et al., ${ }^{[70]}$ the efficiency of the plasma source was determined to be $3 \%$ by Langmuir probe measurements in pure Ar plasma under the same parameters as used for depositions.

\section{ETP-CVD ZnO Opto-Electronic Properties and Growth Modes}

In this Section, the development of the microstructure and opto-electrical properties of ETP-CVD ZnO:Al with film thickness is presented. In particular, the limitations to opto-electrical properties at low film thicknesses (and their causes) are highlighted.

A typical trend of the electrical properties as a function of film thickness (i.e. the resistivity gradient) for ETP-CVD grown $\mathrm{ZnO}$ :Al is shown in Figure 2 . The resistivity decreases from $1.2 \Omega \cdot \mathrm{cm}$ for $\mathrm{a} \sim 37 \mathrm{~nm}$ thick film, to $1 \cdot 10^{-3} \Omega \cdot \mathrm{cm}$ for $700 \mathrm{~nm}$. Fay et al. ${ }^{[49]}$ and Chen et al. ${ }^{[71]}$ each similarly report resistivity decreasing across three orders of magnitude through a comparable thickness range for LP-CVD grown ZnO:B and aerosol-assisted (AA)-CVD grown $\mathrm{ZnO}: \mathrm{Ga}$ respectively. Note that the gradient here is driven by an increase in carrier mobility with film thickness (from 0.02 to $\sim 20 \mathrm{~cm}^{2} / \mathrm{Vs}$ ). The carrier density is comparatively

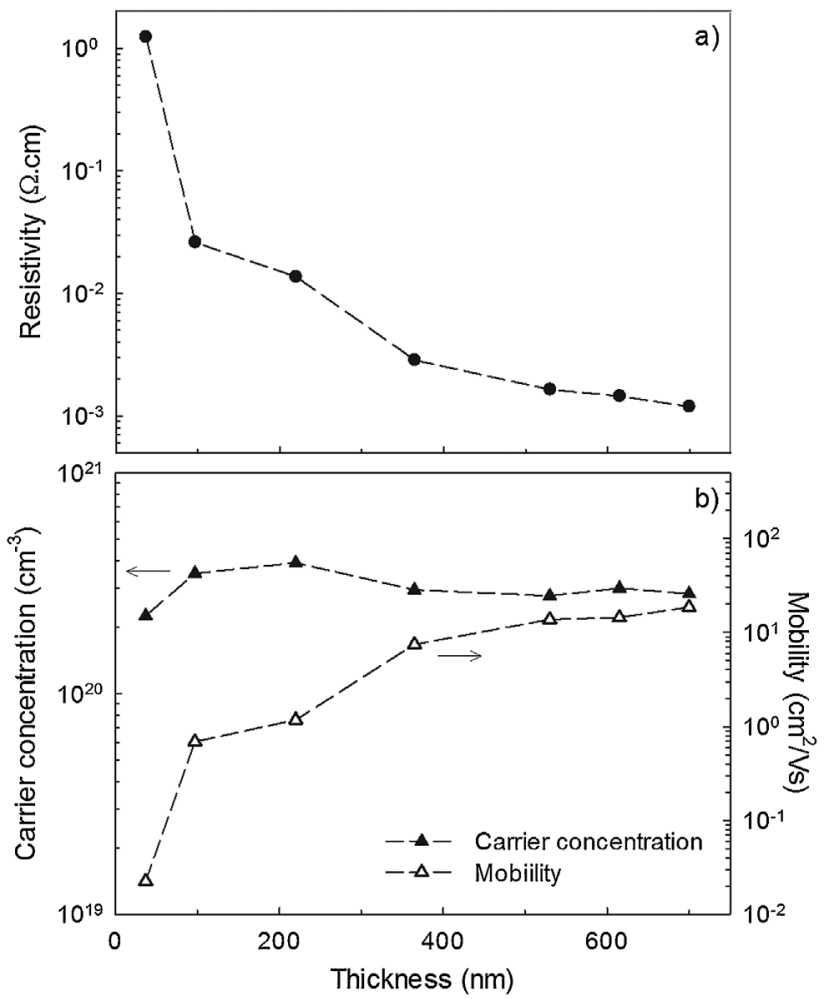

Figure 2. (a) Resistivity and (b) carrier concentration and mobility, of $\mathrm{ZnO}$ :Al grown by ETP-CVD at $200^{\circ} \mathrm{C}$, as a function of film thickness.

much less dependent on film thickness, varying within the range $2 \cdot 10^{20}-4 \cdot 10^{20} \mathrm{~cm}^{-3}$. Upon examination of a cross-sectional TEM image of a layer from this series (Figure 3), the low mobility values for the thinner films are correlated with a combination of small grain sizes $(<50 \mathrm{~nm})$ and therefore high grain boundary density, and high void

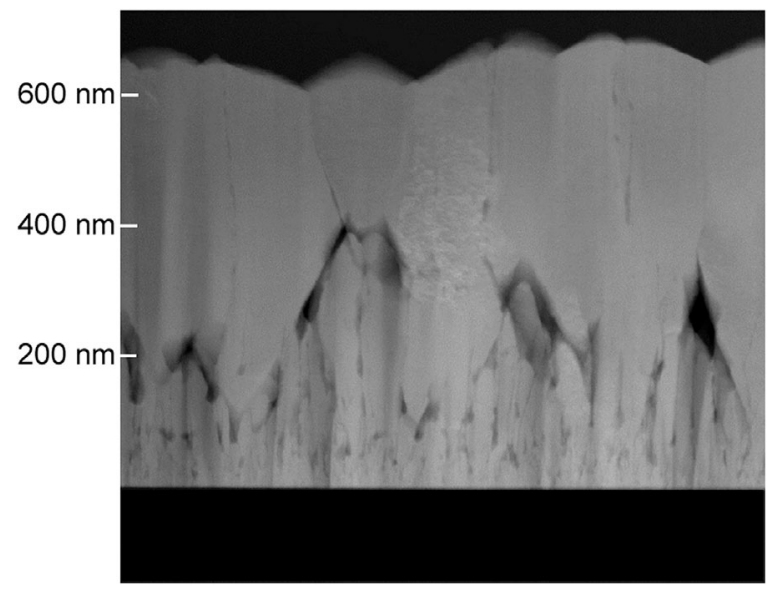

Figure 3. High angle annular dark field - scanning transmission electron microscope (HAADF-STEM) cross sectional image of a $\mathrm{ZnO}$ :Al film grown by ETP-CVD on a $\mathrm{SiO}_{2} / \mathrm{Si}$ substrate. 
density in the earlier growth stages. On the contrary, after significant morphological changes whereby some grains grow both vertically and laterally at the expense of neighbouring grains, in the upper part of the film the lateral grain size is significantly larger $(>150 \mathrm{~nm})$, which is correlated with the higher mobility values for thicker films. Indeed, the steepest resistivity gradient is observed in the first $400 \mathrm{~nm}$ of growth, and this is the region in which the most substantial morphological changes occurred. These correlations are indicative of the significant role that grain boundaries have on $\mathrm{ZnO}: \mathrm{Al}$ conductivity, as discussed next.

Ellmer et al. ${ }^{[72,73]}$ have previously shown that carrier mobility is significantly higher in single crystal ZnO as compared to polycrystalline $\mathrm{ZnO}$, but only when the carrier density is below $<10^{21} \mathrm{~cm}^{-3}$. For higher carrier densities, the mobilities for single crystal and polycrystalline doped-ZnO are comparable. From this Ellmer theorised that for low in-grain carrier concentrations, the grain-boundaries in polycrystalline films present a potential barrier to carrier transport, whereas for sufficiently high carrier concentrations, the width of these potential barriers may be reduced sufficiently to enable tunnelling transport. Voids are also expected to introduce potential barriers to transport, and should be too wide for tunnelling to occur at all. From these considerations, it is evident that for the given carrier concentrations reported here, $\sim(2-4) \cdot 10^{20} \mathrm{~cm}^{-3}$, the presence of grain boundaries are indeed detrimental and their frequency should be minimised. Note that the reduction in carrier mobility caused by grain boundaries and voids is referred to as grain boundary scattering.

Grain boundary scattering is one of a number of scattering mechanisms that limit carrier mobility in polycrystalline materials (another common source of scattering being ionised impurities such as Al-dopants in $\mathrm{ZnO}$ ). In previous work ${ }^{[67]}$ we used a combination of optical and electrical measurements to discern the extent of grain boundary scattering in $\mathrm{ZnO}: \mathrm{Al}$. The methodology was based on the fact that electron mobility values extracted from modelling spectroscopic ellipsometry data (Section 3.2) only represent in-grain properties (owing to the short interaction distance between the probing photons and the electrons in the film which is significantly smaller than the grain size) whereas those measured directly from Hall measurements are representative of the effective film properties, and so any difference between the two values can be attributed to grain boundary scattering. For $\mathrm{ZnO}$ :Al films of comparable microstructure to that shown in Figure 3, we demonstrated that at film thicknesses of $100 \mathrm{~nm}$ the effective mobility is low $\left(\sim 8 \mathrm{~cm}^{2} / \mathrm{Vs}\right)$, as was seen in Figure 2 , but the in-grain mobility is much higher $\left(\sim 18 \mathrm{~cm}^{2} / \mathrm{Vs}\right)$, indicating that conductivity is limited by grain boundary scattering.
However, as film thickness increased the difference between the two values reduced as the effective mobility increased, until at $600 \mathrm{~nm}$, the two values were equal $\left(\sim 18 \mathrm{~cm}^{2} / \mathrm{Vs}\right)$, indicating the negligible influence of grain boundaries at that stage. ${ }^{[67]}$

Increasing carrier mobility for low film thickness is particularly sought after in TCOs, since the alternative routes to reducing resistivity of increasing either carrier concentration or film thickness lead to the detrimental effects of: (a) reducing carrier mobility by increasing ionised impurity scattering (in the former case); and (b) reducing transmittance (in both cases). For instance, Figure 4 shows the effects of film thickness on the transmittance spectrum of $\mathrm{ZnO}: \mathrm{Al}$ films. Increasing the film thickness reduces transmittance in the ranges $400-800 \mathrm{~nm}$ (due to scattering) and 1200-1800 nm (due to free carrier absorption). Although carrier concentration is constant here, the increasing film thicknesses results in a greater absolute number of carriers, and a similar effect at 1200-1800 nm would be observed if carrier concentration was increased and film thickness kept constant. Hence, given the significant role of carrier mobility for determining TCO quality, and given the effect of grain boundaries and voids on the carrier mobility, it is highly important to understand the growth mechanisms responsible for film formation. This is discussed next.

In order to gain insight into the early stages of growth, ZnO:Al films with thicknesses $6-37 \mathrm{~nm}$ were deposited onto $\mathrm{Si}_{3} \mathrm{~N}_{4}$ TEM window substrates, and top-view HAADFSTEM images were taken, as shown in Figure 5. Here, the deposition conditions were identical to those used for the data in Figures 2 and 3 . It is evident that the grain density is particularly high, yielding a fully closed film at only $6 \mathrm{~nm}$ film thickness, consisting of densely packed and small

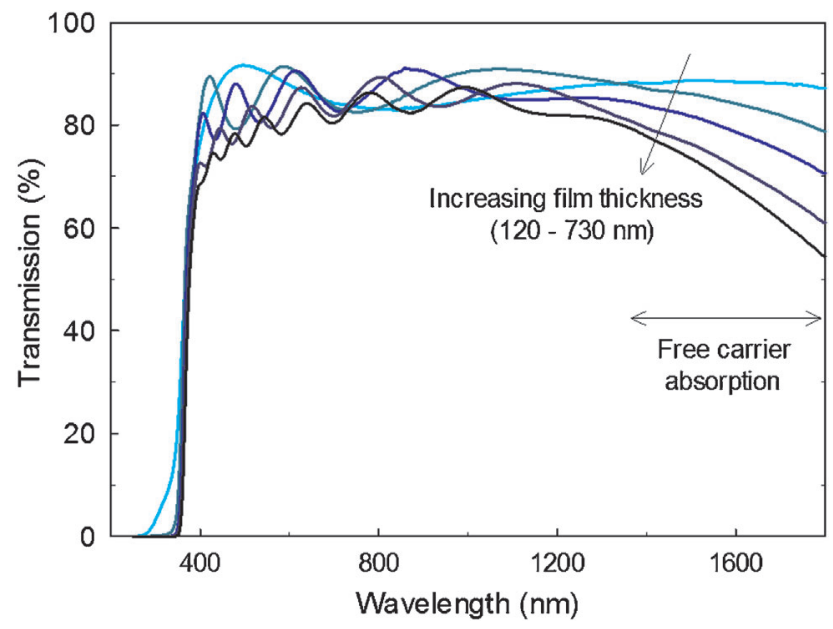

Figure 4. Transmittance of ETP-CVD deposited ZnO:Al/glass as a function of film thickness demonstrating the effect of free carrier absorption. 


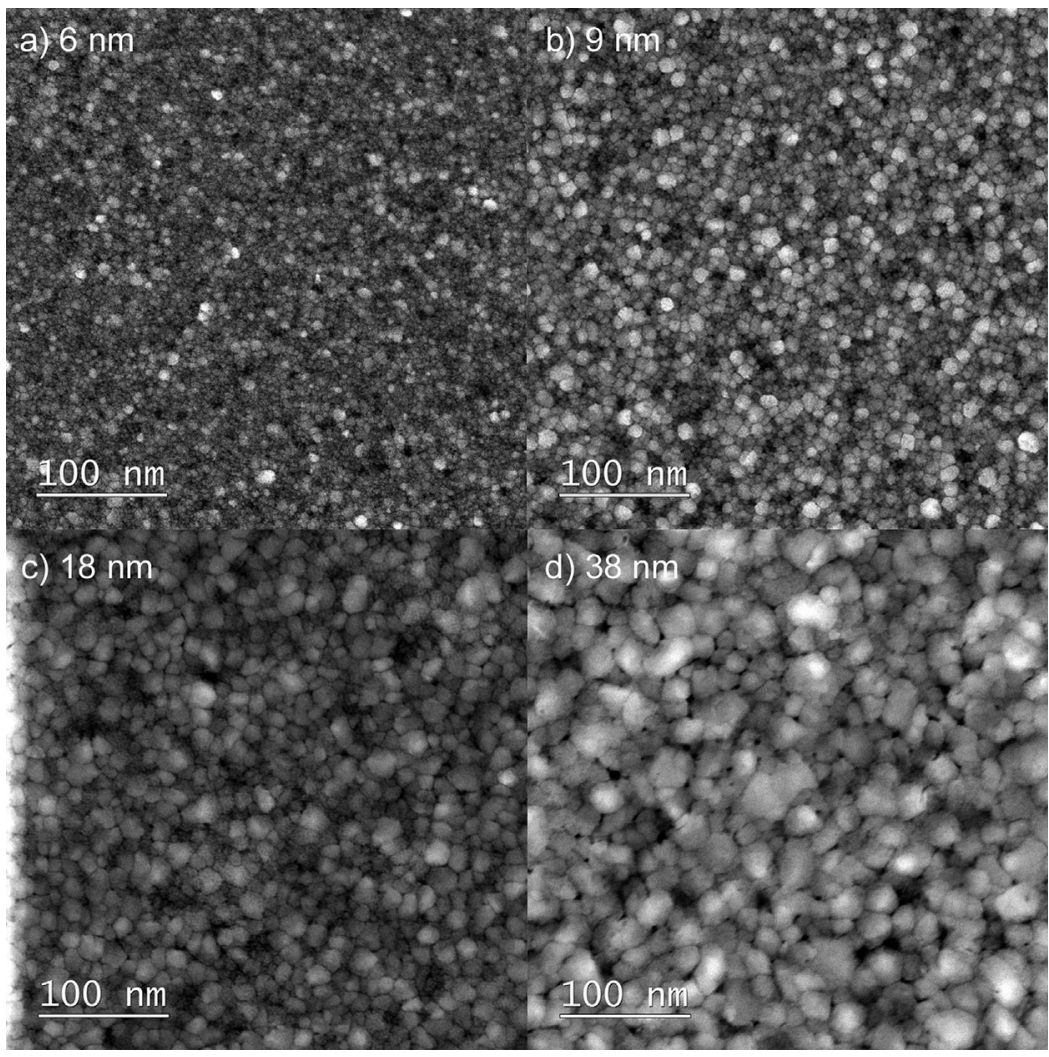

Figure 5. Top-view high angle annular dark-field scanning transmission electron microscope (HAADF-STEM) images of ZnO:Al layers of varying thickness (indicated on each image), deposited by ETP-CVD onto $\mathrm{Si}_{3} \mathrm{~N}_{4}$ TEM window substrates which were held at a temperature of $200{ }^{\circ} \mathrm{C}$. Even for thicknesses as low as $6 \mathrm{~nm}$, the layers are fully closed, indicating the high nucleation density achievable for the given growth conditions.

$(<5 \mathrm{~nm})$ grains. Electron diffraction patterns revealed that the predominant orientation of all these films is $\langle 0002\rangle^{1}$, as evidenced by the dominance of the $\{10 \overline{1} 0\}^{2}$ and $\{11 \overline{2} 0\}$ rings and absence of the $\{0002\}$ ring in a measurement that is sensitive to planes perpendicular to the substrate (an example of a diffraction pattern is shown in the inset of Figure 6). The appearance of rings corresponding to planes that are not parallel to the $<0002>$ axis however indicates that non- $<0002>$ oriented crystals are also

${ }^{1}$ Note that $<>$-brackets denote a family of crystallographic directions, i.e. $<0002>$ accounts for both [0002] and [0o0 $\overline{2}$ ] where []-brackets are for a specific direction. Also, \{\}-brackets denote a family of crystallographic planes, where ()-brackets are for a specific plane, and are used when referencing diffraction data.

${ }^{2}$ When describing materials with a hexagonal crystal structure, such as wurtzite-ZnO, a 4 -index notation scheme is used, i.e. $\{h k i\}$, whereby $i=-(\mathrm{h}+\mathrm{k})$, rather than the more common 3 -index notation, i.e. $\{h k /\}$. The 4 -index notation helps to elucidate any equivalence between specific planes. For instance, a (1010) plane is equivalent to a $(1$ 100) plane but this would not be clear if the 3 -index notation was used. present. This can either be due to the presence of other crystallographic directions, or to an imperfect $<0002>$ texture, characterised by an angular distribution of the $<0002>$ growth directions of the individual crystals with respect to the surface normal. It is a common finding for wurtzite $\mathrm{ZnO}$ films to be primarily $<0002>-$ textured, in particular for highly directional deposition methodologies such as PLD $^{[6-9]}$ and sputtering, ${ }^{[10,11,20,74]}$ and also in some cases for CVD. ${ }^{[21,45,63]}$ However, note that ZnO films have also been reported to be textured in other directions (Table 1) - more frequently for CVD than for PLD or sputtering. When $<0002>$-texture is observed, as in the case here, it is almost exclusively attributed to the $\{0002\}$-planes having the 'lowest surface energy', in reference to values calculated by Fujimura et al. ${ }^{[75]}$ for a number of low-index planes. However, as pointed out by Kajikawa, ${ }^{[76]}$ Fujimura deduced these values simply by counting the density of dangling bonds for various planes, and did not account for the effect of surface reconstructions. In contrast to Fujimura, all other sources cite the $\{10 \overline{1} 0\}$ or $\left\{\begin{array}{lll}11 & \overline{2} & 0\end{array}\right\}$ planes as having lower surface/ cleavage energies, which challenges the perceived cause of $<0002>$ texture in $\mathrm{ZnO}$ films. ${ }^{[77-80]}$ It may be that a vertically developing $<0002>$-oriented crystal is the most energetically favourable configuration since in this way the overall surface energy is minimised by the

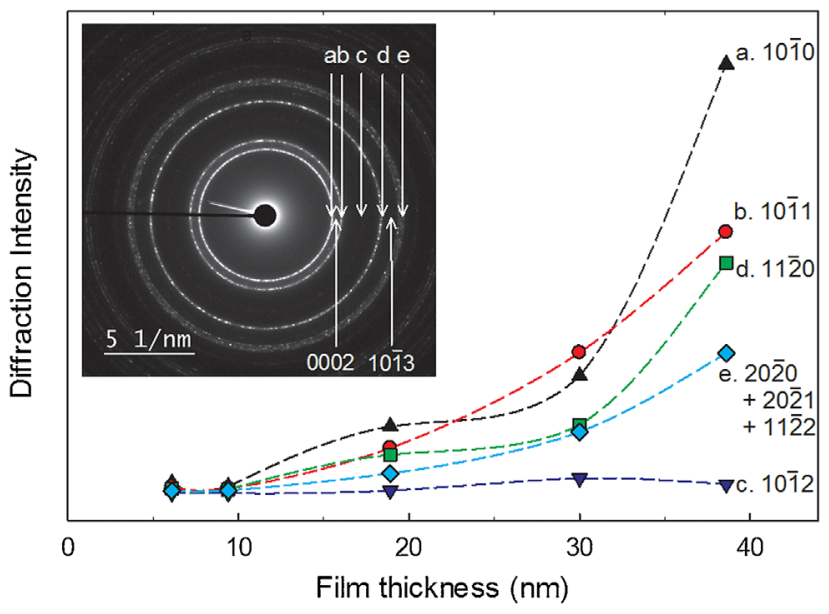

Figure 6. Development of intensity of different electron diffraction rings with film thickness. Inset: an example of the electron diffraction pattern used to determine the quantitative data. 
development of low energy $\{10 \overline{1} 1\}$ or $\{10 \overline{1} 2\}$ side facets. $\mathrm{ZnO}$ texture has been reviewed by Kajikawa, and he posits that the issue is significantly more complex than a mere process of minimising surface energy, concluding that texture also depends on; (a) varying sticking probabilities from plane-to-plane; (b) adatom diffusion between facets; (c) adatom diffusion between grains; and (d) grain-growth processes. Addressing point (a), for wurtzite crystals composed of atoms A and B Ishihara et al. ${ }^{[81]}$ and Li et al. ${ }^{[82]}$ each suggest that in the case whereby the arriving species are individual A and B adatoms (not A-B molecules) the sticking probability is higher on the $c$-axis $(<0002>)$, due to the polarity of these planes. Indeed, Groenen et al. ${ }^{[69]}$ posited that film formation in the case of ETP-CVD ZnO:Al proceeds via the adsorption of $\mathrm{Zn}$ and $\mathrm{O}$ atoms - not ZnO units - which would be consistent with the observation of $<0002>$-texture here. However, it is likely that film texture is defined by a combination of competing mechanisms, and the selection of any one general rule is too simplistic. In any case, referring to Figure 6, a key observation is that the (rotationally averaged) intensities of the $\left\{\begin{array}{lll}10 & \overline{1} & 0\end{array}\right)$ and $\left\{\begin{array}{lll}11 & \overline{2} & 0\end{array}\right\}$ rings increase super-linearly with film thickness, which shows that the extent of $<0002>$-texture increases with film thickness. Indeed, X-ray diffraction data (not shown) for $35 \mathrm{~nm}$ and $100 \mathrm{~nm}$ thick films reveal an entirely $<0002>$-textured film, and no diffraction peaks from other orientations were observed at this stage $(\theta-2 \theta$ X-ray diffraction is sensitive to planes parallel to the substrate). From considering all results, we propose the following growth mechanism: The initial presence of predominantly $<0002>$-texture in combination with the high initial grain density leads to a region of significant grain-competition during which the fastergrowing $<0002>$-oriented grains quench any slowergrowing non- $<0002>$ grains that are present (as well as smaller $<0002>$ grains), and at this stage the high grain density restricts any lateral grain-growth. As a consequence of this, voids form above the quenched grains (Figure 3 and a schematic of the mechanism in Figure 7). Upon continued growth, in the upper part of the film the grain density is sufficiently reduced following grain competition to allow the remaining grains (now with a higher degree of $<0002>$ texture) to develop laterally as well as vertically. Further occurrences of grain competition may occur at later stages.

\subsection{The Role of Grain Density}

In the growth mechanism described above, the high grain density $\left(>10^{4} \mu \mathrm{m}^{-2}\right.$, estimated from Figure $5(b)$ at early growth stages) is one of the key factors responsible for the observed growth mode: in contrast, a regime whereby sparser isolated nuclei would form would allow lateral development of grains at an earlier stage, even for

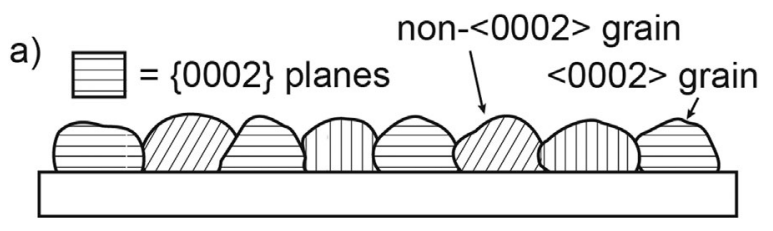

b)

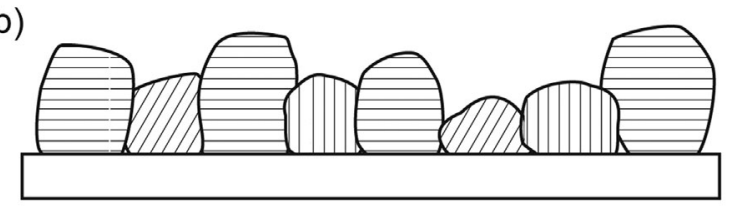

c)

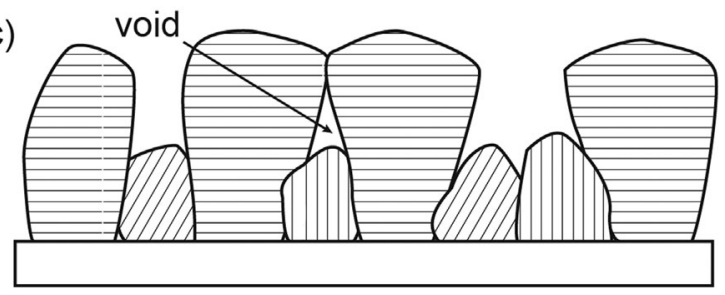

Figure 7. Schematic of proposed early growth mode of $\mathrm{ZnO}$ :Al films having strong resistivity gradient: (a) At nucleation stage the grain density is high and a number of grains are oriented with their $\{0002\}$ planes parallel to the substrate, but other orientations are also present; (b) as a result of the high grain density, grains only develop vertically and not laterally, with the $<0002>$-oriented grains growing at a faster rate; (c) non$<0002>$ grains are quenched by the faster growing $<0002>$ grains, leaving voids and allowing the $<0002>$ grains to develop both vertically and laterally. Note that the light lines within the grains represent $\{0002\}$ planes.

similarly $<0002>$-textured films. Early growth studies of $\mathrm{RF}$ sputtered $\mathrm{ZnO}$ show significantly lower grain densities $\left(<5 \cdot 10^{2} \mu \mathrm{m}^{-2}\right)$, with grains of comparable size to here but isolated from one another, mimicking a more VolmerWeber island-like growth mode. ${ }^{[83]} \mathrm{Kim}$ et al. ${ }^{[84]}$ and Ogata et $a .^{[85]}$ each demonstrated the ability to shift growth modes between two-dimensional (high grain density) and three-dimensional (low grain density) for sputtering and metal organic vapour phase epitaxy (MOVPE) respectively, by changing substrate temperature. Elsewhere, using either ALD or molecular beam epitaxy, ${ }^{[86,87]}$ quasi layer-by-layer growth (for instance, island laterals widths of up to $50 \mathrm{~nm}$ when just $1.5 \mathrm{~nm}$ thick) has been achieved by careful selection of epitaxial substrates or by application of pretreatments to the substrates (the latter highlighting the importance of binding sites for nucleation). A similarly favourable growth mode was reported for PLD of $\mathrm{ZnO}$ on sapphire, whereby sparsely distributed nuclei $\left(10^{2} \mu \mathrm{m}^{-2}\right)$ have lateral grain sizes of $20-50 \mathrm{~nm}$ when just $0.6 \mathrm{~nm}$ in height. ${ }^{[88]}$ Naturally, different techniques can yield both high and low grain densities, and therefore differing growth modes, depending on the processing conditions, and there are insufficient early-growth studies in the literature to provide general statements as to how nucleation probability/grain density of $\mathrm{ZnO}$ varies from 
one technology to another. Nevertheless, it can be stated that the general characteristics of PE-CVD appear to be ideal for high grain densities: Firstly, the high flux of arriving species leads to a high supersaturation ratio for nucleation, and this coupled with low substrate temperatures results in a small critical size for the forming nuclei. ${ }^{[89,90]}$ This allows adatoms to form numerous small nuclei with a low probability of desorption. Secondly, the low substrate temperatures further inhibits both: (a) diffusion of adatoms towards established nuclei; and (b) migration and coalescence of neighbouring nuclei. In contrast, thermal-CVD methods operate at higher substrate temperatures, and sputtering methods typically deliver much lower growth rates. Note that a high growth rate is also expected to exacerbate the void formation within the region of grain competition. In view of these considerations, in order to enhance grain size and reduce void density at early growth stages, deposition conditions should be sought that can: (a) reduce the flux of arriving growth species and therefore reduce nucleation density; and (b) reduce the dominance of $<0002>$ grains to enable lateral growth of non- $<0002>$ grains. However, such conditions are sought whilst maintaining low substrate temperatures in order to satisfy the specifications of device fabrication processes.

\section{Plasma Chemistry and Its Influence on the Resistivity Gradient}

\subsection{Controlling the Resistivity Gradient}

We have previously reported a study demonstrating that the extent of the resistivity gradient, and in particular, the resistivity in the low thickness range $(50-400 \mathrm{~nm})$ could be controlled by varying the DEZ flow rate $(17-27 \mathrm{sccm})$, whilst keeping all other flow rates, including $\operatorname{Ar}(1000 \mathrm{sccm})$, $\mathrm{O}_{2}(100 \mathrm{sccm})$, and TMA $(0.5 \mathrm{sccm})$ constant. ${ }^{[42]}$ (all deposition conditions are found i ${ }^{[42]}$ ). First, we review the main findings, and then (Section 5.2) present new results which reveal the plasma chemistry and growth mechanisms responsible.

In Figure 8a, the effect of increasing the DEZ flow rate on the resistivity gradient is shown. Whilst the thicknessdependence of the resistivity for the low DEZ flow rate condition $(17 \mathrm{sccm})$ is highly comparable to that demonstrated in Section 4, the high DEZ condition $(27 \mathrm{sccm})$ generates much lower resistivity films in the thickness range $50-500 \mathrm{~nm}$, resulting in a shallower resistivity gradient over the whole range. The improvement is immediately apparent even for film thicknesses as low as $50 \mathrm{~nm}$, the resistivity being reduced from $8 \cdot 10^{-2}$ to $2 \cdot 10^{-3} \Omega \cdot \mathrm{cm}$ upon increasing the DEZ flow rate. At $300 \mathrm{~nm}$ film thickness a resistivity as low as $4 \cdot 10^{-4} \Omega \cdot \mathrm{cm}$ was achieved. Just as demonstrated in Section 4 , the resistivity gradient in both high and low DEZ conditions is driven
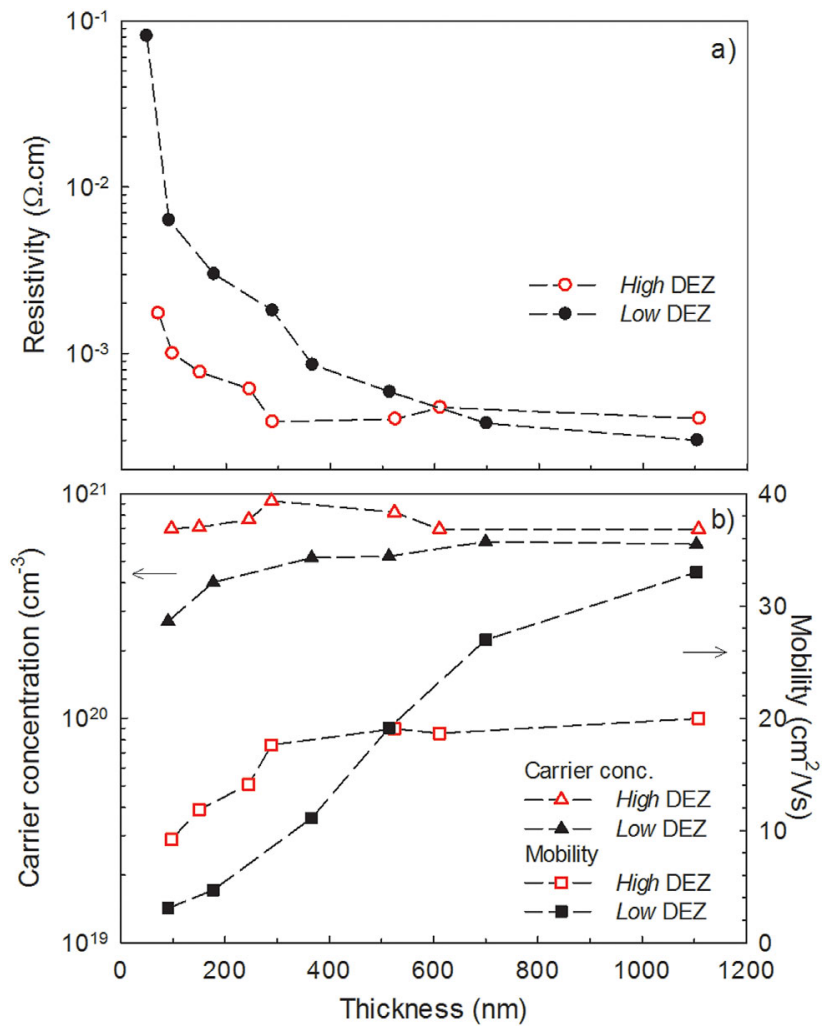

Figure 8. (a) Resistivity and (b) mobility and carrier concentration, of ZnO:Al as a function of thickness for low DEZ (17 sccm) and high DEZ $(27 \mathrm{sccm})$ conditions. Re-drawn from. ${ }^{[42]}$

by an increase in mobility, as shown in Figure $8 b$, but note that for the high DEZ conditions the mobility values are already relatively higher in the $50-500 \mathrm{~nm}$ thickness range (2-3 times) which accounts for much of the difference between the two conditions. For thicker films, the mobility trends cross over and it is the low DEZ conditions that demonstrate the higher carrier mobilities, but for the remainder of this discussion focus is kept on the $50-500 \mathrm{~nm}$ range. Significantly, note also that the high DEZ conditions yielded much lower growth fluxes $\left(1.9 \cdot 10^{15}\right.$ at $\cdot \mathrm{cm}^{-2} \cdot \mathrm{s}^{-1}$, as determined using the film density obtained from Rutherford back-scattering and the film thickness) compared to the low DEZ conditions $\left(5.5 \cdot 10^{15}\right.$ at $\left.\cdot \mathrm{cm}^{-2} \cdot \mathrm{s}^{-1}\right)$ resulting in lower growth rates $\left(0.25 \mathrm{~nm} \cdot \mathrm{s}^{-1}\right.$ compared to $\left.0.75 \mathrm{~nm} \cdot \mathrm{s}^{-1}\right)$. From a crosssectional HAADF STEM image of a $1 \mu \mathrm{m}$ thick ZnO film generated by low DEZ conditions (Figure 9a) we showed that the microstructural development with film thickness is similar to that shown in Figure 4; a high void density is observed in the first $500 \mathrm{~nm}$ of growth, presumably due to the competing grain mechanism discussed above. XRD $\theta-2 \theta$ measurements confirmed that this corresponded with a dominance of $<0002>$-texture within the film (Figure 10, black and blue data, see the large $\{0002\}$ peak). 


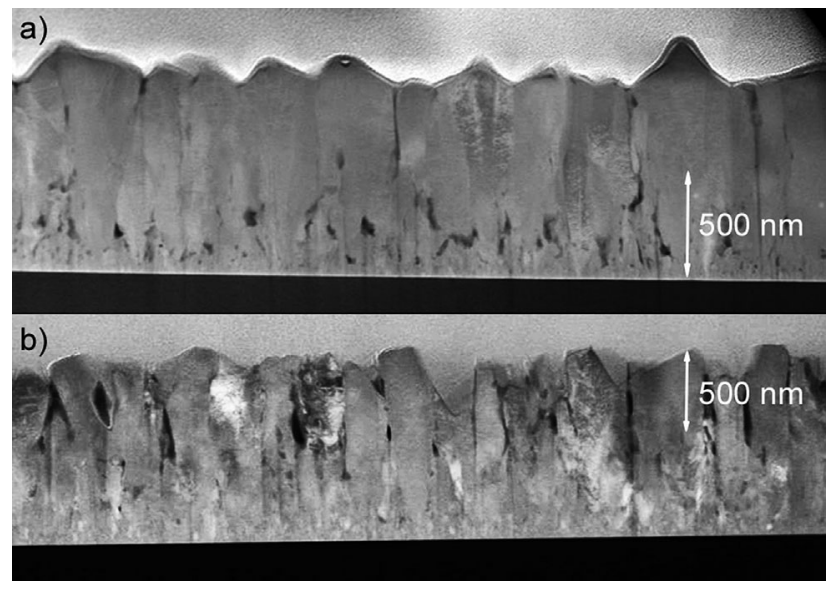

Figure 9. Cross-sectional HAADF STEM images for: (a) low DEZ flow rate; and (b) high DEZ flow rate. Re-drawn from. ${ }^{[42]}$

The high DEZ conditions on the other hand resulted in significantly denser films in the first $500 \mathrm{~nm}$ of growth (Figure 9b), with very little voiding observed, and this was identified as the cause of the mobility improvement. Indeed, grain size in the initial stages of growth $(100 \mathrm{~nm}$ film thickness) was larger for the high DEZ conditions $(60-80 \mathrm{~nm})$ than the low DEZ conditions $(30-50 \mathrm{~nm})$. From the XRD results, the denser films corresponded with a reduction in dominance of $<0002>$-texture, and the emergence of reflections from $\left\{\begin{array}{lllll}10 & \overline{1} & 1\end{array}\right\},\left\{\begin{array}{llll}10 & \overline{1} & 2\end{array}\right\}$, and $\left\{\begin{array}{lll}10 & \overline{1} & 3\end{array}\right\}$ planes (red data). In Section 4, it was inferred that the unfavourable growth mechanism that resulted in high void density was a result of high grain densities, high growth rates and a dominant $<0002>$-texture. Our demonstration $^{[42]}$ that film quality can be significantly improved by reducing growth rates and enhancing non-

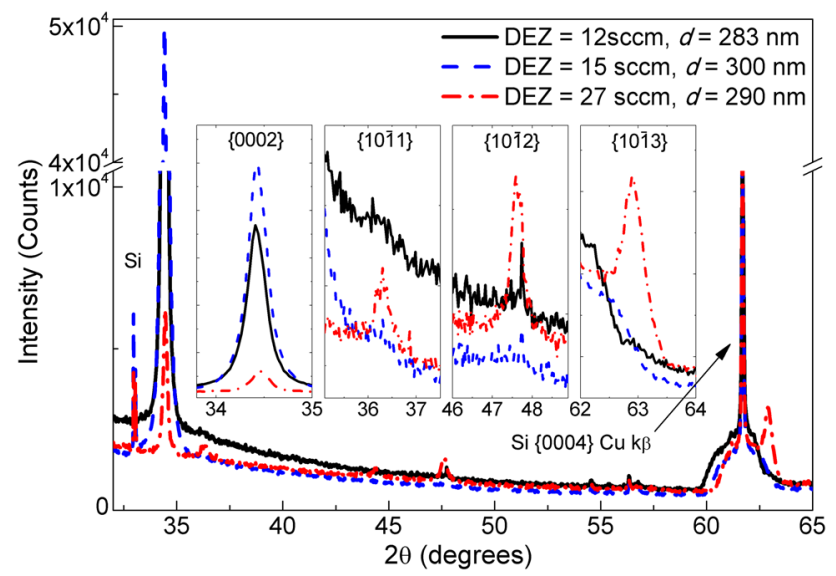

Figure 10. XRD $\theta-2 \theta$ diffractograms of $\mathrm{ZnO}$ :Al films, grown using varying DEZ flow rates. Whilst for low DEZ flow rates only reflections from $\{0002\}$ are observed, at higher flow rates, peaks from other planes emerge, and the $\{0002\}$ peak is suppressed. Re-drawn from. ${ }^{[42]}$
$<0002>$ crystal orientations is therefore fully consistent with this.

Note also that the carrier densities were higher for high DEZ conditions and this is attributed to the higher Al concentration (1.4 At.\%) compared to the low DEZ conditions (0.9 At.\%) which is thought to result from the slower growth rates enabling more efficient incorporation of $\mathrm{Al}$ (film stoichiometry, in terms of $\mathrm{Zn} / \mathrm{O}$ ratio and $\mathrm{H}$ and $C$ content, was otherwise found to be identical by RBS). In the next section however, focus remains on the influence of the plasma conditions on the film microstructure since the relative increases of carrier mobility were more significant than that of carrier density (upon increase of DEZ). Moreover, the carrier densities for both conditions are constant with thickness, whereas the mobility gradients strongly correlate with the respective resistivity gradients, and strongly correlate with the observed microstructure at certain film thicknesses.

\subsection{Plasma Processes and the Role of Oxygen in the Growth Mechanism}

Now, the gas phase chemistry is addressed by first describing the global reaction route to $\mathrm{ZnO}$ synthesis from DEZ and oxygen, and then, the reactions which presumably take place in an argon-fed expanding thermal plasma. On the basis of these reaction paths the trends of the stable species monitored by means of mass spectrometry (MS) are interpreted. Finally, the plasma chemistry studies are correlated with the film properties described in Section 5.1.

A global reaction of DEZ with oxygen leads to the formation of $\mathrm{ZnO}$ according to (1):

$$
\begin{aligned}
& \mathrm{Zn}\left(\mathrm{C}_{2} \mathrm{H}_{5}\right)_{2}+(14-\chi) / 2 \mathrm{O}_{2} \\
& \quad \rightarrow \mathrm{ZnO}+\chi \mathrm{CO}+(4+\chi) \mathrm{CO}_{2}+5 \mathrm{H}_{2} \mathrm{O}
\end{aligned}
$$

where $x$ is in the range (0-4). By tuning the $\mathrm{O}_{2} / \mathrm{DEZ}$ ratio injected in the plasma, the reaction can shift from $\mathrm{CO}$ to $\mathrm{CO}_{2}$ production, which are detected by mass-spectrometry. ${ }^{[69]}$

Generally, there are electrons, $\mathrm{Ar}$ atoms, ions and metastables present in an Ar plasma and only $\mathrm{Ar}^{+}$ions and electrons play an important role in precursor dissociation processes. ${ }^{[33,35,68,69]}$ As it was previously reported for the ETP growth of $\mathrm{ZnO}: \mathrm{Al}, \mathrm{Ar}^{+}$ions dissociate precursor molecules and allow the formation of hydrocarbon species ${ }^{[69]}$ according to:

$$
\begin{aligned}
& \mathrm{Ar}^{+}+\mathrm{Zn}\left(\mathrm{C}_{2} \mathrm{H}_{5}\right)_{2} \rightarrow \mathrm{ZnC}_{2} \mathrm{H}_{5}^{+}+\mathrm{C}_{2} \mathrm{H}_{5}+\mathrm{Ar} \\
& \mathrm{Ar}^{+}+\mathrm{Zn}\left(\mathrm{C}_{2} \mathrm{H}_{5}\right)_{2} \rightarrow \mathrm{ZnC}_{2} \mathrm{H}_{5}+\mathrm{C}_{2} \mathrm{H}_{5}^{+}+\mathrm{Ar}
\end{aligned}
$$

Previous studies carried out on organosilicon precursors such as hexamethyldisiloxane (HMDSO), ${ }^{[33]}$ showed that the charge exchange reaction rate between $\mathrm{Ar}^{+}$ 
and HMDSO is at least one order of magnitude higher (about $(4 \pm 2) \cdot 10^{-16} \mathrm{~m}^{3} \cdot \mathrm{s}^{-1}$ ) than the charge exchange reaction rate of $\mathrm{Ar}^{+}$with $\mathrm{O}_{2}$ molecules. Also, the reaction rate of $\mathrm{Ar}^{+}$with trimethylaluminum was found to be $(5.9 \pm 0.5) \cdot 10^{-16} \mathrm{~m}^{3} \cdot \mathrm{s}^{-1},{ }^{[91]}$ which is in the same order of magnitude as the $\mathrm{Ar}^{+}$reaction with HMDSO. Thus, for the present study, it is reasonable to assume that the charge exchange reactions of $\mathrm{Ar}^{+}$with DEZ (2-3) are faster than those with $\mathrm{O}_{2}$, and should be the first to proceed - these reactions are indeed possible since Jiao et al. ${ }^{[91]}$ demonstrated branching ratios for reaction (2) and (3) to be equal to $32 \%$ and $28 \%$, respectively. The other routes to organic and $\mathrm{Zn}$-containing ions are less dominant, each below $10 \% .{ }^{[92]}$ Note that direct dissociation of the first and second $\mathrm{Zn}-\mathrm{C}$ bond in a DEZ molecule require $2.27 \mathrm{eV}$ and $0.95 \mathrm{eV}$ respectively, ${ }^{[93]}$ but due to the plasma expansion, a low electron temperature develops in the downstream region, in the range of $0.25-0.35 \mathrm{eV}^{[70]}$ which is not sufficient for molecule dissociation: The electron impact dissociation rate constant for an electron energy of $0.3 \mathrm{eV}$, assuming a Maxwellian electron energy distribution function, is in the range of $10^{-24}-10^{-25} \mathrm{~m}^{3} \mathrm{~s}^{-1}$, which is many orders of magnitude below the charge exchange constant rates of $\mathrm{Ar}^{+}$ions and molecules $\left(10^{-15}-10^{-16}\right.$ $\mathrm{m}^{3} \mathrm{~s}^{-1}$ for HMDSO, $\mathrm{SiH}_{4}{ }^{\left[{ }^{[35]}\right.}$ and $\mathrm{C}_{2} \mathrm{H}_{2}{ }^{[38]}$ ). Nevertheless, electrons are involved in the dissociative recombination reactions with $\mathrm{ZnC}_{2} \mathrm{H}_{5}{ }^{+}$and $\mathrm{C}_{2} \mathrm{H}_{5}{ }^{+}$that follow reaction (2) and (3). Further dissociative charge exchange with $\mathrm{Ar}^{+}$ ions can also occur. For instance reactions (4) and (5) may follow reaction (2):

$$
\begin{aligned}
& \mathrm{ZnC}_{2} \mathrm{H}_{5}^{+}+\mathrm{e}^{-} \rightarrow \mathrm{Zn}+\mathrm{C}_{2} \mathrm{H}_{5} \\
& \mathrm{C}_{2} \mathrm{H}_{5}+\mathrm{Ar}^{+} \rightarrow \mathrm{CH}_{3}^{+}+\mathrm{CH}_{2}+\mathrm{Ar}
\end{aligned}
$$

and reactions (6) and (7) may follow reaction (3):

$$
\begin{aligned}
& \mathrm{C}_{2} \mathrm{H}_{5}^{+}+\mathrm{e}^{-} \rightarrow \mathrm{C}_{2} \mathrm{H}_{4}+\mathrm{H} \\
& \mathrm{ZnC}_{2} \mathrm{H}_{5}+\mathrm{Ar}^{+} \rightarrow \mathrm{Zn}+\mathrm{C}_{2} \mathrm{H}_{5}^{+}+\mathrm{Ar}
\end{aligned}
$$

The produced alkyl radicals and $\mathrm{H}$ atoms allow development of the hydrocarbon chemistry.

Based on the plasma source efficiency of about $3 \%$, as derived from Langmuir probe measurements, the $\mathrm{Ar}^{+} / \mathrm{DEZ}$ ratio is equal to 2 at low DEZ and about 1 at high DEZ conditions (Table 2) and so $\mathrm{Ar}^{+}$ions are always in surplus compared to DEZ in the experiments described in Section 5.1. This surplus of $\mathrm{Ar}^{+}$ions can now contribute to the production of atomic $O$ via charge exchange reactions (8) with $\mathrm{O}_{2}$, followed by dissociative recombination (9) of the produced $\mathrm{O}_{2}{ }^{+}$with electrons:

$$
\mathrm{Ar}^{+}+\mathrm{O}_{2} \rightarrow \mathrm{Ar}+\mathrm{O}_{2}^{+}
$$

Table 2. Flow rates of $\mathrm{Ar}^{+}$ions and precursors at low and high DEZ conditions.

\begin{tabular}{lcc}
\hline Substance & $\begin{array}{c}\text { Flow rate } \\
\text { (sccm) }\end{array}$ & $\begin{array}{c}\text { Flow rate } \\
\text { (molecules.s-1) }\end{array}$ \\
\hline $\mathrm{Ar}^{+}$ & 30 & $1.5 \cdot 10^{19}$ \\
$\mathrm{O}_{2}$ & 100 & $4.5 \cdot 10^{19}$ \\
$\mathrm{DEZ}$ (low DEZ) & 17 & $7.5 \cdot 10^{18}$ \\
$\mathrm{DEZ}$ (high DEZ) & 27 & $1.2 \cdot 10^{19}$ \\
\hline
\end{tabular}

$$
\mathrm{O}_{2}^{+}+\mathrm{e}^{-} \rightarrow \mathrm{O}+\mathrm{O}
$$

Here, the charge exchange reaction rate is significantly lower $\left(6 \cdot 10^{-17} \mathrm{~m}^{3} / \mathrm{s}\right)$, compared to the rate of dissociative recombination of molecular oxygen $\left(1 \cdot 10^{-13} \mathrm{~m}^{3} / \mathrm{s}\right)$, pointing out that the charge exchange reaction (8) is the rate-limiting step for atomic oxygen formation. As mentioned above, the charge exchange rate of $\mathrm{Ar}^{+}$with $\mathrm{O}_{2}$ (8) is lower than the one of $\mathrm{Ar}^{+}$with DEZ (2-3). Oxygen is however also expected to affect the hydrocarbon and oxidation chemistry in its molecular form by reacting with the alkyl radicals produced in (4-7). (N.b. atomic Al should be produced following similar reaction routes to those for $\mathrm{Zn}$ production, between TMA, $\mathrm{Ar}^{+}$and $\mathrm{e}^{-}$, but note that TMA flows are only 2-3\% that of DEZ).

Under oxygen-rich conditions, such as low DEZ, it can be expected that the surplus of $\left(\mathrm{Ar}^{+}, \mathrm{e}^{-}\right)$can react with $\mathrm{O}_{2}$, according to reactions (8-9), with a theoretical maximum depletion of $\mathrm{O}_{2}$ equal to $33 \%$ (ratio between flow rates of $\mathrm{Ar}^{+}$ions and molecular oxygen from the Table 2) in the absence of DEZ molecules. Experimentally, the measured $\mathrm{O}_{2}$ depletion (from MS) is shown in Figure $11(\mathrm{~m} / \mathrm{z}=32)$ as a function of DEZ flow rate. The $\mathrm{O}_{2}$ depletion in only $\mathrm{Ar} / \mathrm{O}_{2}$ plasma (without DEZ and TMA) was measured here to be significantly low and equal to $5 \%$, which is the result of atomic oxygen recombination losses producing $\mathrm{O}_{2}$ at the walls of the deposition chamber. However, for a DEZ flow rate of $27 \mathrm{sccm}$ the $\mathrm{O}_{2}$ depletion obtained from the mass-spectrometry measurements is almost $80 \%$, i.e. larger than the theoretical maximum of $33 \%$ for the case of $\mathrm{O}_{2}$ depletion only occurring from interaction with $\left(\mathrm{Ar}^{+}, \mathrm{e}^{-}\right)$. From this comparison it can be concluded that $\mathrm{O}_{2}$ is consumed mostly through combustion of DEZ fragments produced through reactions (4-7) in an $\mathrm{Ar} / \mathrm{O}_{2} / \mathrm{DEZ}$ plasma and heterogeneous reactions at the surface of the growing layer. For the same $\mathrm{O}_{2}$ flow rate as used in this work, the $\mathrm{O}_{2}$ depletion measured by Groenen et al. ${ }^{[69]}$ was equal to $25 \%$, in agreement with the trend reported in Figure 11. It is worth mentioning that this agreement in terms of $\mathrm{O}_{2}$ depletion occurs even in the presence of different $\mathrm{Ar}^{+}$flow rates, i.e. $\sim 3.8 \cdot 10^{19}$ ions $\cdot \mathrm{s}^{-1}$ in the 


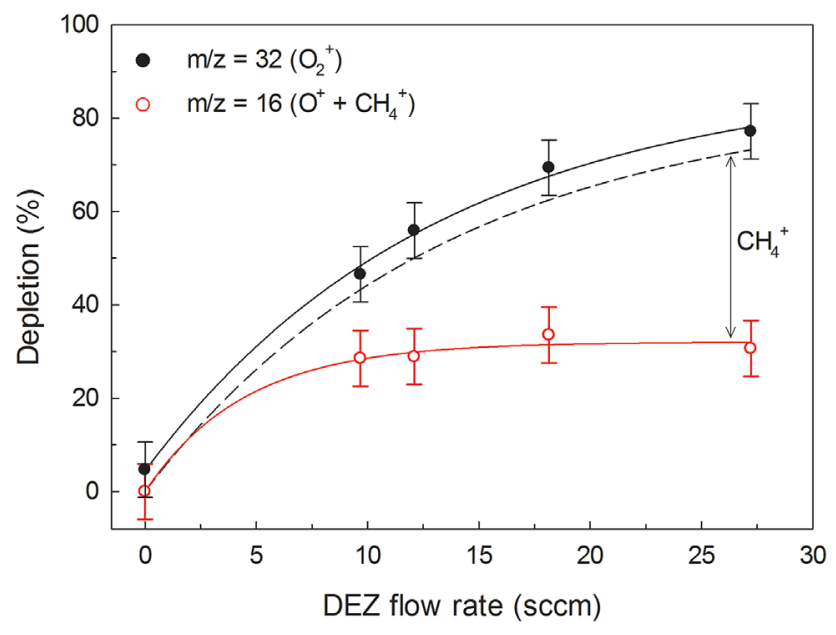

Figure 11. Depletion of the $m / z=16$ and 32 as a function of DEZ flow rate. Black dashed line: expected depletion profile, if $m / z=16$ would be related only to $\mathrm{O}^{+}$, based on the cracking pattern of $\mathrm{O}_{2}$ in the mass-spectrometer. Reduction of $\mathrm{m} / \mathrm{z}=16$ depletion, caused by the increasing contribution of $\mathrm{CH}_{4}{ }^{+}$to the 16 amu signal, is also shown.

work of Groenen et al. and $1.5 \cdot 10^{19}$ ions $\cdot \mathrm{s}^{-1}$ here. This leads to the general conclusion that the oxygen depletion is controlled by the injected DEZ flow rate, provided that there is a surplus of $\mathrm{Ar}^{+}$ions with respect to DEZ to promote DEZ dissociation (which is indeed satisfied in both cases of low DEZ and high DEZ). Moreover, it is plausible to conclude that the direct reaction of DEZ with molecular oxygen does not occur, since otherwise the $\mathrm{O}_{2}$ depletion in Figure 11 would increase linearly with the injected DEZ flow rate. Note that there was no $\mathrm{Zn}$ observed in the mass-spectra, pointing to the low gas phase concentration of $\mathrm{Zn}$-related products. After reaction (2) and (3), possible reactions that oxygen could take part in are;

$$
\begin{aligned}
& \mathrm{ZnC}_{2} \mathrm{H}_{5}+\mathrm{O}_{2} \rightarrow \mathrm{Zn}+\mathrm{CO}+\mathrm{CH}_{4}+\mathrm{OH} \\
& \mathrm{C}_{2} \mathrm{H}_{5}+\mathrm{O}_{2} \rightarrow \mathrm{CO}+\mathrm{CH}_{4}+\mathrm{OH}
\end{aligned}
$$

Appreciate that the fact that $\mathrm{O}_{2}$ is not completely depleted indicates that in these experiments there is always sufficient $\mathrm{O}_{2}$ to promote the deposition of carbon-free $\mathrm{ZnO}$.

The dashed line in Figure 11 shows the expected depletion profile of $\mathrm{O}^{+}$based on the cracking pattern of $\mathrm{O}_{2}$. Since the $\mathrm{m} / \mathrm{z}=16$ line is related to both $\mathrm{O}^{+}$and $\mathrm{CH}_{4}{ }^{+}$, the deviation of the measured $m / z=16$ line from the dashed line is attributed entirely to $\mathrm{CH}_{4}{ }^{+}$production.

This deviation, and hence the production of $\mathrm{CH}_{4}{ }^{+}$, is observed to increase with DEZ flow rate as it is a result of DEZ decomposition. At a DEZ flow rate of $27 \mathrm{sccm}$, the contribution of $\mathrm{CH}_{4}{ }^{+}$in $\mathrm{m} / \mathrm{z}=16$ is up to $60 \%$. Such a strong increase in $\mathrm{CH}_{4}{ }^{+}$is in agreement with a production of other hydrocarbons shown in Figure 12. Indeed, signal intensities of several oxygen- and hydrocarbon-containing masses are measured and plotted in Figure 12 as a function of the DEZ flow rate. Here, the linear/superlinear trends of lines associated purely to hydrocarbon species $(\mathrm{m} / \mathrm{z}=27,29)$ deviate from the saturating trends of those that are also associated with oxygen containing ions $(\mathrm{m} / \mathrm{z}=18,28,44)$. This difference can be related to the oxygen involvement in the formation of the latter. The presence and increase of $\mathrm{C}_{2} \mathrm{H}_{5}{ }^{+}$for example, may support $\mathrm{C}_{2} \mathrm{H}_{6}$ production, which may form as a result of the following reaction;

$$
\left(\mathrm{ZnC}_{2} \mathrm{H}_{5}\right)_{2}+\mathrm{H}_{2} \mathrm{O} \rightarrow \mathrm{ZnC}_{2} \mathrm{H}_{5} \mathrm{OH}+\mathrm{C}_{2} \mathrm{H}_{6}
$$

Ultimately, upon consideration of the plasma pathways described above, and the experimental results shown in Figure 11 and 12, it is clear that the DEZ flow rate can be used to control $\mathrm{O}_{2}$ consumption by two means, with higher DEZ flow rates leading to: (a) greater $\mathrm{O}_{2}$ consumption via combustion reactions; and (b) reduced availability of $\mathrm{Ar}^{+}$ ions to dissociate $\mathrm{O}_{2}$. If it is assumed that each $\mathrm{Ar}^{+}$ion reacts with one DEZ molecule, then the surplus of $\mathrm{Ar}^{+}$ions available for reactions with $\mathrm{O}_{2}$ is $7.5 \cdot 10^{18}$ molecules $\cdot \mathrm{s}^{-1}$ when $17 \mathrm{sccm}$ of DEZ is used, and $2.5 \cdot 10^{18}$ molecules $\cdot \mathrm{s}^{-1}$ when $27 \mathrm{sccm}$ is used. This is only $6-17 \%$ of the total injected $\mathrm{O}_{2}\left(4.48 \cdot 10^{19}\right.$ molecules $\left.\cdot \mathrm{s}^{-1}\right)$, and a significant proportion of the remainder is involved in combustion reactions, accounting for the $60-80 \%$ depletion levels. The three times reduction in the atomic $O$ flux available, as DEZ flow rate is increased, corresponds well with the three times reduction in growth rate, indicating that film growth is limited by the atomic $\mathrm{O}$ flux.

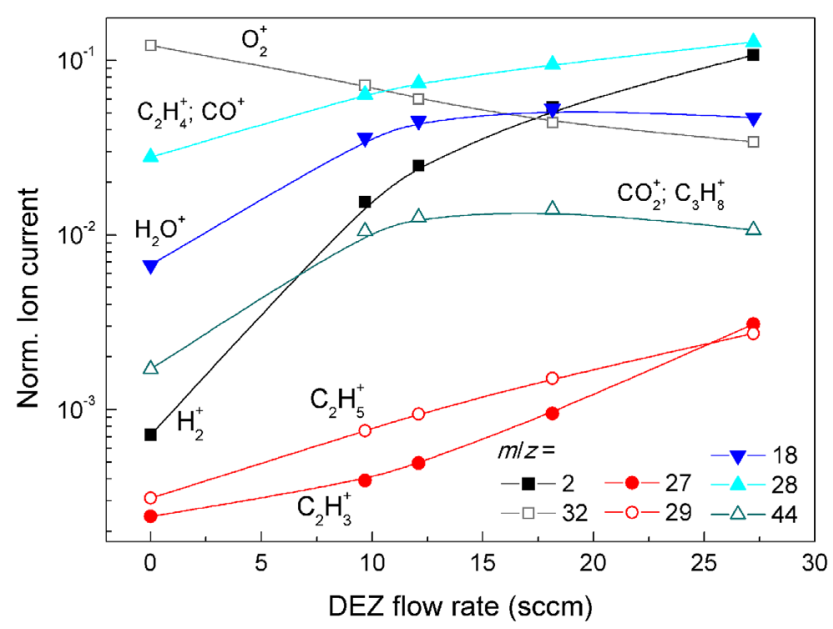

Figure 12. Ion current of reaction products (corresponding $\mathrm{m} / \mathrm{z}$ values are shown in the legend) obtained from massspectrometry measurements and normalized to ion current of argon $(m / z=40)$, plotted as a function of DEZ flow rate. 
In view of the effects of increasing the DEZ flow rate that we have observed (i.e. a reduced growth rate, reduced $<0002>$-texture, and enhanced lateral grain size in the early growth stages) and the inferred observation that the atomic $\mathrm{O}$ arrival rate is reduced, a new growth mechanism is postulated for the high DEZ conditions: Firstly, the reduction in atomic $O$ flux (and growth rate) is expected to reduce the grain density at early growth stages. This is because, when reducing the partial pressure of a condensate, the supersaturation ratio is decreased, and this in turn, causes the critical size for nucleation to increase (n.b. nuclei smaller than the critical size will desorb) therefore nucleation probability, and hence grain density, will be reduced - this, in itself, should be beneficial in terms of promoting larger grains at early growth stages. Furthermore, reducing the growth rate should enable lateral growth of grains during any period of grain competition, thereby enhancing film density and reducting void density. Finally, and perhaps most significantly, we believe that the reduction of the atomic $\mathrm{O}$ flux is also the direct cause of the reduction of $<0002>$-texture, according to the following: The $\{0002\}$ planes are highly polar, and recall that this polarity may be the cause of them having a higher sticking coefficient than non-polar planes for $\mathrm{Zn}$ and $\mathrm{O}$ adatoms, thereby driving the higher growth rates. However, this polarity should also mean that growth on $\{0002\}$ planes is more limited by the atomic $O$ flux available than growth on non-polar planes - for instance, a fully Zn-terminated $\{0002\}$ facet can only grow upon arrival of $\mathrm{O}$, whereas a $\mathrm{Zn}$ - and O-terminated $\{10 \overline{1} 0\}$ facet can grow upon arrival of either $\mathrm{Zn}$ or $\mathrm{O}$. In the low DEZ case, the arriving flux of $\mathrm{O}$ and $\mathrm{Zn}$ are of comparable magnitude $\left(7.5 \cdot 10^{18}\right.$ atoms $\left./ \mathrm{s}\right)$ thereby enabling steady growth of polar planes, but in the high DEZ case, the arriving flux of $\mathrm{O}\left(2.5 \cdot 10^{18}\right.$ atoms/s) is 5 times lower than $\mathrm{Zn}\left(1.2 \cdot 10^{19}\right.$ atoms/s) (assuming that each $\mathrm{Ar}^{+}$ion reacts with one DEZ molecule, and then each surplus $\mathrm{Ar}^{+}$ion reacts with one $\mathrm{O}_{2}$ molecule), and should therefore severely limit the dominance of $\{0002\}$-growth. This

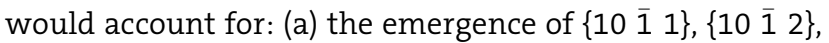
and $\{10 \overline{1} 3\}$ peaks in the XRD patterns; and (b) lateralgrowth of $<0002>$-oriented grains in non- $<0002>$ directions (thereby increasing lateral grain size in $100 \mathrm{~nm}$ thick films). The proposed mechanism would therefore follow the schematic shown in Figure 13, whereby the vertical and lateral growth rates of differently oriented grains are more uniform than in Figure 7 and non- $<0002>$ grains are no longer quenched. Note that the scenarios depicted by these schematics are only applicable to the first few hundred nms of growth: It can be seen from Figure 9 that at later stages of growth $(1 \mu \mathrm{m})$, there is more voiding for the high DEZ conditions, presumably due to grain competition later on

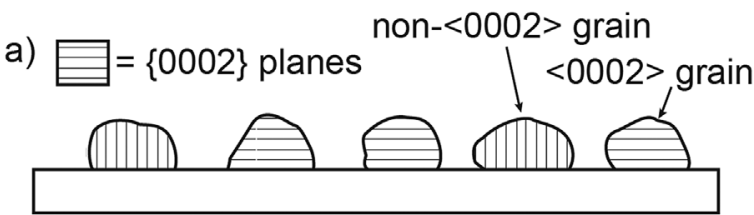

b)

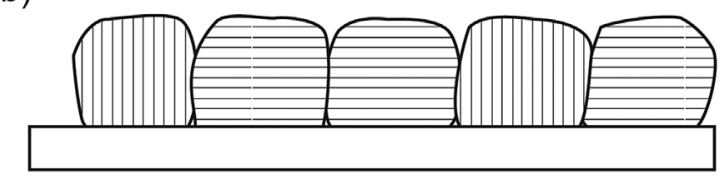

c)

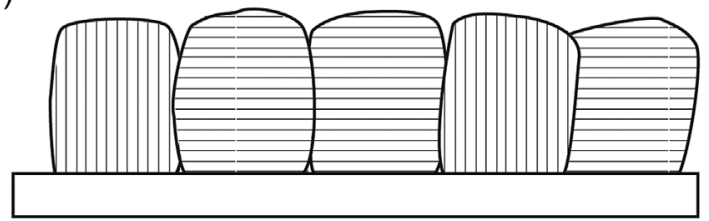

Figure 13. Schematic of proposed early growth mode of $\mathrm{ZnO}: \mathrm{Al}$ films having reduced resistivity gradient. The high DEZ conditions reduces the atomic oxygen flux, thereby reducing nucleation probability (and therefore grain density), growth rate, and the dominance of $<0002>$-oriented crystals (in comparison to the growth mechanism depicted in Figure 7 ).

in film development, and also due to inclined faceting of $<10 \overline{1} 1>$ - grains.

As well as microstructural improvements induced by the increase of DEZ flow rate, the electron carrier density was also observed to increase (Figure 8 ). This may be explained either by the slower growth rates enabling higher $\mathrm{Al}$ incorporation (0.9 at.\% for low DEZ conditions and 1.4\% for high DEZ conditions), or by the lower $\mathrm{O}$ atomic flux being available for $\mathrm{Al}_{2} \mathrm{O}_{3}$ formation, leading to more $\mathrm{Al}$ being present in the active form. We should point out that the TMA flow rate was not controlled in synchronism with DEZ flow rate in these experiments: It was constant at $0.5 \mathrm{sccm}$. However, this flow rate was significantly lower than the DEZ flow rates used, i.e. only $3 \%$ of the DEZ flow rate in low DEZ conditions (17 sccm), and $2 \%$ of the DEZ flow rate in high DEZ conditions $(27 \mathrm{sccm})$, and so the relative change in TMA/DEZ flow rate ratio and the relative change in incorporated $\mathrm{Al}$ are both considered to be negligible with respect to the change in atomic oxygen flux, and we maintain the conclusion that the selection of different crystalline directions is controlled almost exclusively by O-flux.

In separate experiments, the same effects as those seen when increasing DEZ flow rate were replicated by instead reducing the Ar flow from a value of $2200 \mathrm{sccm}$ to 1000 sccm (whilst keeping DEZ flow rate constant) - a similar enhancement of the non-\{0002\} XRD peaks was observed (not shown), along with a reduction in growth rate $\left(0.63 \mathrm{~nm} \cdot \mathrm{s}^{-1}\right.$ to $\left.0.20 \mathrm{~nm} \cdot \mathrm{s}^{-1}\right)$ and resistivity $\left(2 \cdot 10^{-1} \Omega \cdot \mathrm{cm}\right.$ 
for a $450 \mathrm{~nm}$ thick film to $1.5 \cdot 10^{-3} \Omega \cdot \mathrm{cm}$ for a $350 \mathrm{~nm}$ thick film). In this case we presume that the higher Ar flow led to a greater surplus of $\mathrm{Ar}^{+}$ions being available for $\mathrm{O}_{2}$ dissociation, generating a growth mode akin to Figure 7, whereas the lower Ar flow led to a lower surplus of $\mathrm{Ar}^{+}$ions, and a growth mode akin to Figure 13.

Elsewhere, other works have also demonstrated the ability to tune the orientation of CVD grown ZnO films: For undoped $\mathrm{ZnO}$, Fay et al. ${ }^{[61]}$ reported that by increasing substrate temperatures from $140{ }^{\circ} \mathrm{C}$ to $180^{\circ} \mathrm{C}$, film texture changed from $<0002>$ to $<11 \overline{2} 0>$ and from the same group, Nicolay et al. ${ }^{[94]}$ showed that for higher deposition temperatures still $\left(380^{\circ} \mathrm{C}\right),<0002>$-texture could be regained. Elsewhere, Robbins et al. ${ }^{[62]}$ found that the use of higher $\mathrm{DEZ} / \mathrm{O}_{2}$ ratios led to more random orientations, whereas lower $\mathrm{DEZ} / \mathrm{O}_{2}$ led to $<0002>$-dominated films (in Ref, ${ }^{[62]}$ a parallel plate PECVD system was used). This was attributed to a greater level of adatom surface mobility in the DEZ-poor conditions allowing the densely packed and thermodynamically favourable $\{0002\}$ planes to develop. However, Robbins actually observed higher resistivities when higher $\mathrm{DEZ} / \mathrm{O}_{2}$ flows were used and more random film orientations were obtained. Indeed, the reader should note that in our work we do not attempt to universally state that $<0002>$-textured films will always be electrically more insulating than randomly textured ones - many high quality conductive $\mathrm{ZnO}$ are strongly $<0002>$-textured ${ }^{[2,5]}$ but merely that for the growth mode present in these experiments, <0002>-texture exacerbates detrimental grain competition in the case of very high grain densities. In support of our results, Hahn et al. ${ }^{[95]}$ reports (using thermal-CVD) that the use of higher $\mathrm{Zn} / \mathrm{O}$ precursor ratios generated $\mathrm{ZnO}$ films with a more random orientation than for lower $\mathrm{Zn} / \mathrm{O}$ ratios. In this case, the growth rate was higher for the high $\mathrm{Zn} / \mathrm{O}$ conditions, which indicates that the $O$ arrival rate may be a more influential parameter for affecting film microstructure, compared to growth rate.

\section{Final Considerations and Conclusions}

It is particular important in the field of TCO process development to obtain sufficiently conductive films for as low a film thickness as possible, to minimise parasitic absorption, and to reduce deposition times and material usage. In thin-film solar cells the sheet resistance of the transparent front electrode should not exceed $10 \Omega / \square$, which corresponds to a bulk resistivity of $4 \cdot 10^{-4} \Omega \cdot \mathrm{cm}$ for a $400 \mathrm{~nm}$ film. In some cases, there are very strict requirements for the thickness of the TCO, e.g. in Siheterojunction solar cells, the TCO thickness must be maintained at $75 \mathrm{~nm}$ for anti-reflective purposes. ${ }^{[12]}$ In view of these requirements, the ETP-CVD technique (and indeed, PECVD in general) faces intrinsic challenges due to the frequently observed resistivity gradient: At low film thicknesses, the lateral grain sizes are typically too small, limiting the electron mobility and therefore conductivity. In this work, the causes of the small grain sizes, high grain boundary density, and high void density are identified as the high nucleation probability, high growth rates and $<0002>$-texture. However, we have shown that the growth mechanism can be manipulated by careful consideration of the plasma chemistry responsible for the delivery of depositing species. Increasing the DEZ flow rate results in the reduction of the atomic $O$ arriving at the substrate, thereby quenching the dominance of $<0002>$-grains, and reducing grain density and growth rates, ultimately yielding a more compact large-grained film. These findings expand the understanding of both: (a) the plasma chemistry involved in the gas phase of an $\mathrm{Ar} / \mathrm{DEZ} / \mathrm{O}_{2}$ plasma; and (b) the growth mechanisms of ETP-CVD ZnO at the substrate surface. It is the remote nature of the ETP-CVD methodology that allows for these two processes to be considered separately. These insights may guide future process development. Ultimately, for ETP-CVD ZnO:Al, low bulk resistivities $\left(4 \cdot 10^{-4} \Omega \cdot \mathrm{cm}\right)$ can be obtained at thicknesses of $300 \mathrm{~nm}$, which is in-line with the requirements of thin-film solar cells.

Acknowledgements: The authors acknowledge J. J. L. M. Meulendijks, C. O. van Bommel, and J. J. A. Zeebregts for their technical support. We also acknowledge M. M. A. Burghoorn and TNO Eindhoven for access to UV-VIS measurements. This research has received funding from the European Union's Horizon 2020 research and innovation programme under grant agreement No 641864 (INREP). The research of M. C. has been partially funded by the Netherlands Organization for Scientific Research (NWO, Aspasia program). Solliance is acknowledged for funding the TEM facility.

Figures 8, 9 and 10 are reprinted with permission from " $M$. V. Ponomarev et al., Controlling the resistivity gradient in aluminiumdoped zinc oxide grown by plasma-enhanced chemical vapor deposition, Journal of Applied Physics, 112, 4 (2012)". Copyright 2012, AIP Publishing LLC.

Received: September 30, 2015; Revised: November 10, 2015; Accepted: November 11, 2015; DOI: 10.1002/ppap.201500179

Keywords: deposition; diagnostics; modification; plasma; polymers

[1] A. Mang, K. Reimann, S. Rübenacke, Solid. State. Commun. 1995, 94, 251.

[2] S.-M. Park, T. Ikegami, K. Ebihara, Thin Solid Films 2006, 513, 90.

[3] H. Yoo, Y. H. Lim, B. H. Choi, J. H. Lee, D. C. Shin, Physica. Status. Solidi. 2011, 8, 895.

[4] Y. Song, E. S. Kim, A. Kapila, J. Electron. Mater. 1995, $24,83$.

[5] Y. Igasaki, H. Saito, J. Appl. Phys. 1991, 70, 3613.

[6] V. Craciun, J. Elders, J. G. E. Gardeniers, I. W. Boyd, Appl. Phys. Lett. 1994, 65, 2963-2965. 
[7] S. L. King, J. G. E. Gardeniers, I. W. Boyd, Appl. Surf. Sci. 1996, 96-98, 811.

[8] S. H. Bae, S. Y. Lee, B. Jun Jin, S. Im, Appl. Surf. Sci. 2000, 154$155,458$.

[9] A. Dikovska, P. A. Atanasav, C. Vasilev, I. G. Dimitrov, T. R. Stoyanchov, J. Optoelectron. Adv. Mater. 2005, 7, 1329.

[10] W. L. Dang, Y. O. Fu, J. K. Luo, A. J. Flewitt, W. I. Milne, Superlattice. Microstr. 2007, 42, 89.

[11] Y. Huawa, W. Jing, Y. Yangan, W. Xin, G. Bin, L. Hanchen, D. Yali. Int. Confer. Electron. Mech. Eng. Inf. Technol. (EMEIT) 2011, 2486.

[12] B. Macco, D. Deligiannis, S. Smit, R. A. C. M. M. V. Swaaij, M. Zeman, W. M. M. Kessels, Semiconductor Sci. Technol. 2014, 29, 122001.

[13] Y. Wu, S. E. Potts, P. M. Hermkens, H. C. M. Knoops, F. Roozeboom, W. M. M. Kessels, Chem. Mater. 2013, 25, 4619.

[14] D. Garcia-Alonso, S. E. Potts, C. A. A. van Helvoirt, M. A. Verheijen, W. M. M. Kessels, J. Mater. Chem. C 2015, 3, 3095.

[15] J. Auld, D. J. Houlton, A. C. Jones, S. A. Rushworth, M. A. Malik, P. O'Brien, G. W. Critchlow, J. Mater. Chem. 1994, 4, 1249.

[16] S. Y. Choi, M. J. Kang, T. J. Park, R. Tap, S. Schoemaker, M Willert-Porada, Physica. Status. Solidi. 2006, 203, R73.

[17] C. Chung-Hua, W. Da-Hua, Jpn. J. Appl. Phys. 2014, 53, 11RA05.

[18] J. Hu, R. G. Gordon, Solar. Cells. 1991, 30, 437.

[19] H. Kim, A. Piqué, J. S. Horwitz, H. Murata, Z. H. Kafafi, C. M. Gilmore, D. B. Chrisey, Thin Solid Films 2000, 377-378, 798.

[20] J. B. Lee, H. J. Kim, S. G. Kim, C. S. Hwang, S.-H. Hong, Y. H. Shin, N. H. Lee, Thin Solid Films 2003, 435, 179.

[21] Y. Li, G. S. Tompa, S. Liang, C. Gorla, Y. Lu, J. Doyle, J Vac. Sci. Technol. 1997, 15, 1063.

[22] J. Löffler, R. Groenen, J. L. Linden, M. C. M. van de Sanden, R. E. I. Schropp, Thin Solid Films 2001, 392, 315.

[23] A. Martín, J. P. Espinós, A. Justo, J. P. Holgado, F. Yubero, A. R. González-Elipe, Surf. Coat. Technol. 2002, 151-152, 289.

[24] S. Mehra, M. G. Christoforo, P. Peumans, A. Salleo, Nanoscale 2013, 5, 4400 .

[25] J. J. Robbins, J. Harvey, J. Leaf, C. Fry, C. A. Wolden, Thin Solid Films 2005, 473, 35.

[26] K.-W. Seo, H.-S. Shin, J.-H. Lee, K.-B. Chung, H.-K. Kim, Vacuum 2014, 101, 250

[27] W. W. Wilson, Y. Akira, K. Makoto, T. Kiyoshi, Jpn. J. Appl. Phys. 1994, 33, L283.

[28] M. C. M. van de Sanden, J. M. d. Regt, D. C. Schram, Plasma Sources Sci. Technol. 1994, 3, 501.

[29] R. Engeln, S. Mazouffre, P. Vankan, D. C. Schram, N. Sadeghi, Plasma Sources Sci. Technol. 2001, 10, 595.

[30] M. C. M. van de Sanden, PhD. Thesis 1991, Eindhoven University of Technology.

[31] M. C. M. van de Sanden, R. V. Bercken, D. C. Schram, Plasma Sources Sci. Technol. 1994, 3, 511.

[32] İ. Doğan, N. J. Kramer, R. H. J. Westermann, K. Dohnalová, A. H. M. Smets, M. A. Verheijen, T. Gregorkiewicz, M. C. M. van de Sanden, J. Appl. Phys. 2013, 113, 134306.

[33] M. F. A. M. van Hest B. Mitu, D. C. Schram, M. C. M. van de Sanden, Thin. Solid. Films. 2004, 449, 52.

[34] B. Hoex, A. J. M. van Erven, R. C. M. Bosch, W. T. M. Stals, M. D. Bijker, P. J. van den Oever, W. M. M. Kessels, M. C. M. van de Sanden, Prog. Photovolt.: Res. Appl. 2005, 13, 705.

[35] M. C. M. van de Sanden, R. J. Severens, W. M. M. Kessels, R. F. G. Meulenbroeks, D. C. Schram, J. Appl. Phys. 1998, 84, 2426.

[36] W. M. M. Kessels, C. M. Leewis, M. C. M. van de Sanden, D. C. Schram, J. Appl. Phys. 1999, 86, 4029.

[37] M. Creatore, M. F. A. M. Van Hest, J. Benedikt, M. C. M. van de Sanden, MRS Proceedings 2002, 715, A19.3.1.
[38] M. Creatore, Y. Barrell, J. Benedikt, M. C. M. van de Sanden, Plasma Sources Sci. Technol. 2006, 15, 421.

[39] M. Creatore, W. M. M. Kessels, Y. Barrell, J. Benedikt, M. C. M. van de Sanden, Mater. Sci. Semicond. Process. 2004, 7, 283.

[40] J. Benedikt, D. C. Schram, M. C. M. van de Sanden, J. Phys. Chem. A 2005, 109, 10153-10167.

[41] J. Benedikt, R. V. Woen, S. L. M. van Mensfoort, V. Perina, J. Hong, M. C. M. van de Sanden, Diamond Relat. Mater. 2003, 12, 90.

[42] M. V. Ponomarev, M. A. Verheijen, W. Keuning, M. C. M. van de Sanden, M. Creatore, J. Appl. Phys. 2012, 112, 043708.

[43] M. V. Ponomarev, K. Sharma, M. A. Verheijen, M. C. M. van de Sanden, M. Creatore, J. Appl. Phys. 2012, 111, 063715.

[44] I. Volintiru, M. Creatore, M. C. M. van de Sanden, J. Appl. Phys. 2008, 103, 033704.

[45] I. Volintiru, M. Creatore, B. J. Kniknie, C. I. M. A. Spee, M. C. M. van de Sanden, J. Appl. Phys. 2007, 102, 043709.

[46] K. Sharma, B. L. Williams, A. Mittal, H. C. M. Knoops, B. J. Kniknie, N. J. Bakker, W. M. M. Kessels, R. E. I. Schropp, M. Creatore, J. Photoenergy. 2014, 2014, 253140.

[47] L.-Y. Chen, W.-H. Chen, J.-J. Wang, F. C. -N. Hong, Y.-K. Su, Appl. Phys. Lett. 2004, 85, 5628.

[48] S. Faÿ, L. Feitknecht, R. Schlüchter, U. Kroll, E. Vallat-Sauvain, A. Shah, Sol. Energy Mater. Sol. Cells 2006, 90, 2960.

[49] S. Fay, PhD. Thesis. 2003, Éc. Polytechnique Federale Lausanne.

[50] C. Agashe, O. Kluth, J. Hüpkes, U. Zastrow, B. Rech, M. Wuttig, J. Appl. Phys. 2004, 95, 1911.

[51] C.-C. Kuo, C.-C. Liu, S.-C. He, J.-T. Chang, J.-L. He, J. Nanomater. 2011, 2011, 140697.

[52] G. A. Kumar, M. V. R. Reddy, K. N. Reddy, Res. J. Phys. Sci. 2013, 1, 17.

[53] É. P. d. Silva, M. Chaves, S. F. Durrant, P. N. Lisboa-Filho, J. R. R. Bortoleto, Mater. Res. 2014, 17, 1384.

[54] N. Akin, S. Sebnem Cetin, M. Cakmak, T. Memmedli, S. Ozcelik, J. Mater. Sci.: Mater. Electron. 2013, 24, 5091.

[55] N. Yamamoto, K. Morisawa, ECS Transactions 2014, 58, 45.

[56] B.-Z. Dong, G.-J. Fang, J.-F. Wang, W.-J. Guan, X.-Z. Zhao, J. Appl. Phys. 2007, 101, 033713.

[57] B. H. Choi, H. B. Im, J. S. Song, K. H. Yoon, Thin. Solid. Films. 1990, 193-194, 712.

[58] B. M. Ataev, A. M. Bagamadova, V. V. Mamedov, A. K. Omaev, M. R. Rabadanov, J. Cryst. Growth 1999, 198-199, 1222.

[59] Y. Akira, W. W. Wilson, Y. Masahiro, K. Makoto, T. Kiyoshi, Jpn. J. Appl. Phys. 1991, 30, L1152.

[60] J. Hu, R. G. Gordon, J. Appl. Phys. 1992, 71, 880.

[61] S. Faÿ, U. Kroll, C. Bucher, E. Vallat-Sauvain, A. Shah, Sol. Energy Mater. Sol. Cells 2005, 86, 385.

[62] J. J. Robbins, J. Esteban, C. Fry, C. A. Wolden, J. Electrochem. Soc. 2003, 150, C693.

[63] L. Po-Hsun, H. Chia-Ming, L. Chia-Te, F. Yu-Siang, Y. ShengJhan, Nanoelectronics Conference (INEC) 2013, 187.

[64] R. Groenen, E. R. Kieft, J. L. Linden, M. C. M. van de Sanden, J. Electron. Mater. 2006, 35, 711.

[65] D. İlker, H. J. W. René, C. M. v. d. S. Mauritius, Plasma Sources Sci. Technol 2015, 24, 015030.

[66] D. C. Schram, G. M. W. Kroesen, US Patent No. 4,871,580, European Patent No. 0297637. 1992.

[67] H. C. M. Knoops, B. W. H. van de Loo, S. Smit, M. V. Ponomarev, J.-W. Weber, K. Sharma, W. M. M. Kessels, M. Creatore, J. Vac. Sci. Technol. A 2015, 33, 021509.

[68] W. M. M. Kessels, R. J. Severens, A. H. M. Smets, B. A. Korevaar, G. J. Adriaenssens, D. C. Schram, M. C. M. van de Sanden, J. Appl. Phys. 2001, 89, 2404.

[69] R. Groenen, H. Linden, R. van de Sanden, Plasma Processes and Polymers 2005, 2, 618 
[70] M. F. A. M. V. Hest, J. R. Haartsen, M. H. M. V. Weert, D. C. Schram, M. C. M. van de Sanden, Plasma Sources Sci. Technol. 2003, 12, 539.

[71] S. Chen, N. Noor, I. P. Parkin, R. Binions, J. Mater. Chem. A 2014, 2, 17174.

[72] K. Ellmer, "Electrical properties", in: "Transparent Conductive Zinc Oxide: Basics and Applications in Thin Film Solar Cells" (Eds: K. Ellmer, A. Klein, B. Reich), Springer, Berlin, Germany 2008.

[73] K. Ellmer, R. Mientus, Thin Solid Films 2008, 516, 4620.

[74] K. Saravanakumar, V. Ganesan, N. P. Lalla, C. Gopinathan, K. Mahalakshmi, C. Sanjeeviraja, Adv. Stud. Theor. Phys. 2011, 5, 143.

[75] N. Fujimura, T. Nishihara, S. Goto, J. Xu, T. Ito, J. Cryst. Growth 1993, 130, 269.

[76] Y. Kajikawa, J. Cryst. Growth 2006, 289, 387.

[77] S.-H. Na, C.-H. Park, J. Korean Phys. Soc. 2010, 56, 498.

[78] B. Meyer, D. Marx, Phys. Rev. B 2003, 67, 035403.

[79] A. Wander, F. Schedin, P. Steadman, A. Norris, R. McGrath, T. S. Turner, G. Thornton, N. M. Harrison, Phys. Rev. Lett. 2001, 86, 3811.

[80] F. Claeyssens, C. L. Freeman, N. L. Allan, Y. Sun, M. N. R. Ashfold, J. H. Harding, J. Mater. Chem. 2005, 15, 139.

[81] M. Ishihara, S. J. Li, H. Yumoto, K. Akashi, Y. Ide, Thin Solid Films 1998, 316, 152.
[82] W.-J. Li, E.-W. Shi, W.-Z. Zhong, Z.-W. Yin, J Cryst. Growth 1999, 203, 186.

[83] S. Iping, K. Oshikawa, D. Yamashita, K. Kamataki, G. Uchida, K. Koga, M. Shiratani, N. Itagaki, in Proc. 12th Asia Pacific Phys. Conf. (APPC12), JPS Conf. Proc. 2014, 2, 015064.

[84] K. In-Woo, L. Kyu-Mann, Nanotechnology 2008, 19, 355709.

[85] K. Ogata, K. Maejima, S. Fujita, S. Fujita, J. Cryst. Growth 2003, 248,25

[86] D. Adolph, T. Ive, Appl. Surf. Sci. 2014, 307, 438.

[87] Z. Baji, Z. Lábadi, Z. E. Horváth, G. Molnár, J. Volk, I. Bársony, P. Barna, Cryst. Growth Design 2012, 12, 5615.

[88] C.-Y. Peng, J.-S. Tian, W.-L. Wang, Y.-T. Ho, L. Chang, Appl. Surf. Sci. 2013, 265, 553.

[89] J. D. Major, PhD. Thesis 2008, University of Durham.

[90] R. A. Sigsbee, J. Appl. Phys. 1971, 42, 3904.

[91] C.O. Jiao, C.A. DeJoseph Jr, P. Haaland, A. Garscadden, Int. J. Mass Spectrom. 2000, 202, 345.

[92] C. O. Jiao, C. A. DeJoseph, A. Garscadden, Int. J. Mass Spectrom. 2004, 235, 83.

[93] R. L. Jackson, Chem. Phys. Lett. 1989, 163, 315.

[94] S. Nicolay, M. Despeisse, F. J. Haug, C. Ballif, Sol. Energy Mater. Sol. Cells 2011, 95, 1031.

[95] B. Hahn, G. Heindel, E. Pschorr-Schoberer, W. Gebhardt, Semicond. Sci. Technol. 1998, 13, 788. 